\title{
Vorurteile als Karrierebremse? Ein Versuch zur Erklärung des Glass Ceiling-Phänomens
}

Franck, E ; Jungwirth, C

Posted at the Zurich Open Repository and Archive, University of Zurich ZORA URL: https://doi.org/10.5167/uzh-2761

Journal Article

Originally published at:

Franck, E; Jungwirth, C (1998). Vorurteile als Karrierebremse? Ein Versuch zur Erklärung des Glass Ceiling-Phänomens. Schmalenbachs Zeitschrift für betriebswirtschaftliche Forschung, 50(12):1083-1097. 


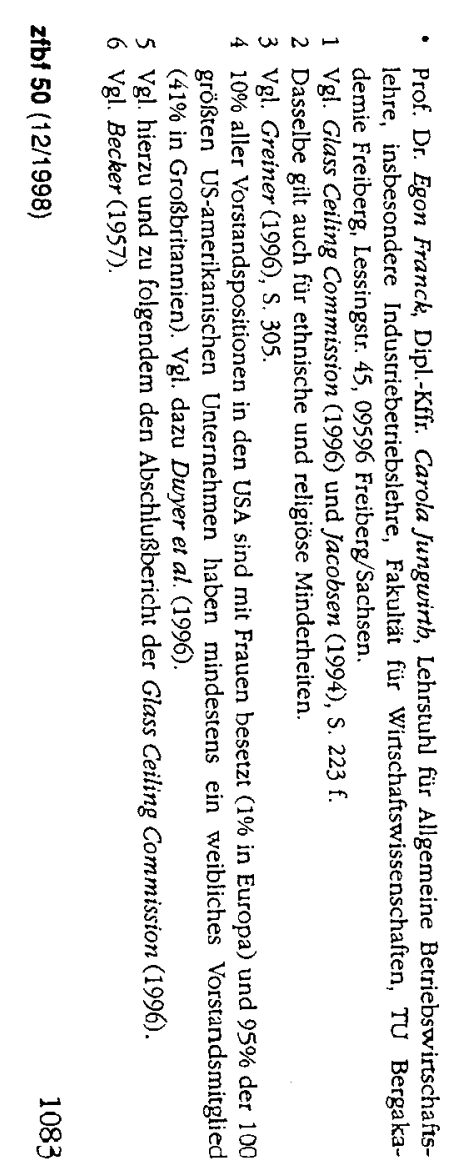

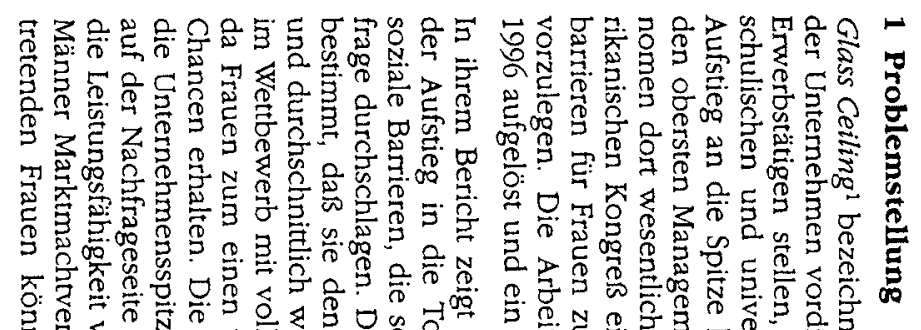

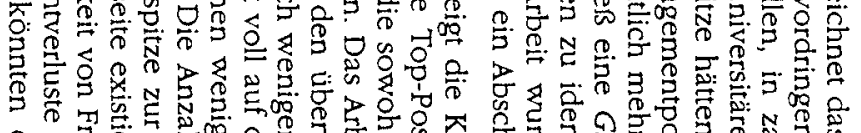

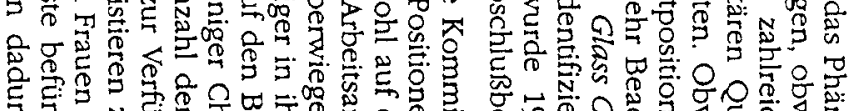

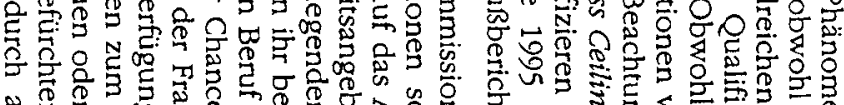
웡

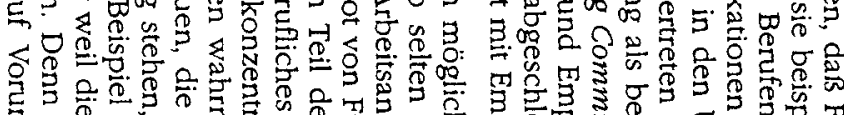

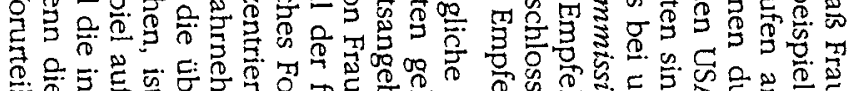

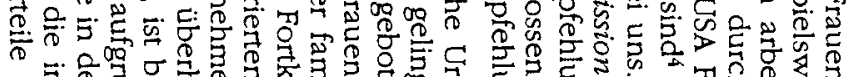

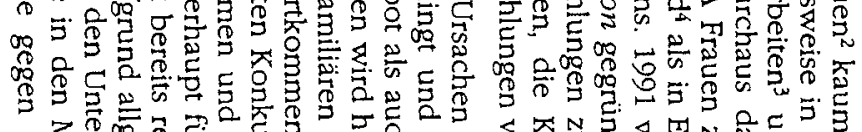

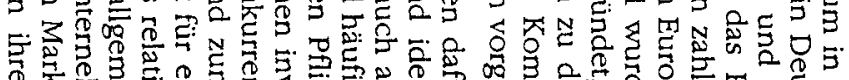
等

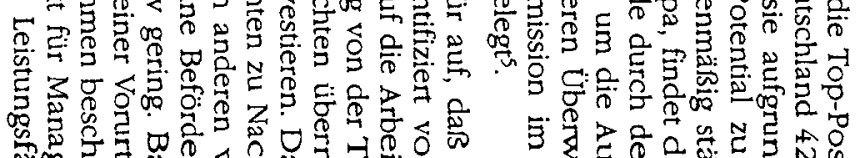

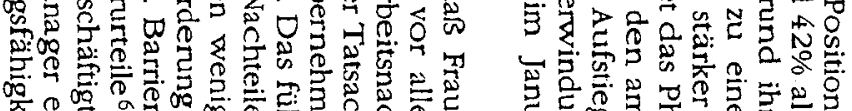

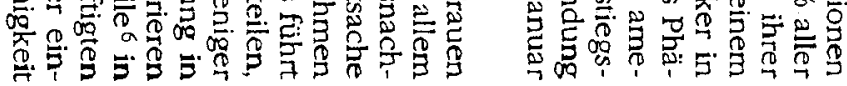

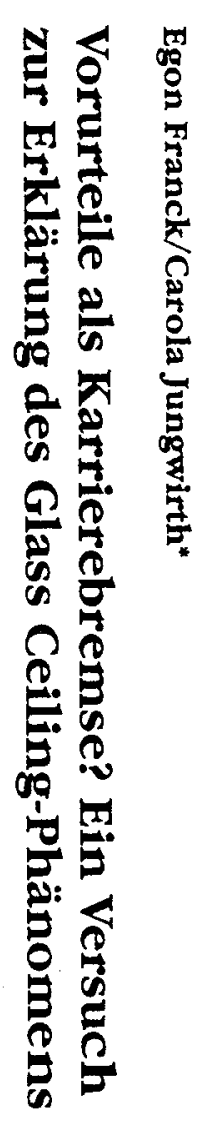



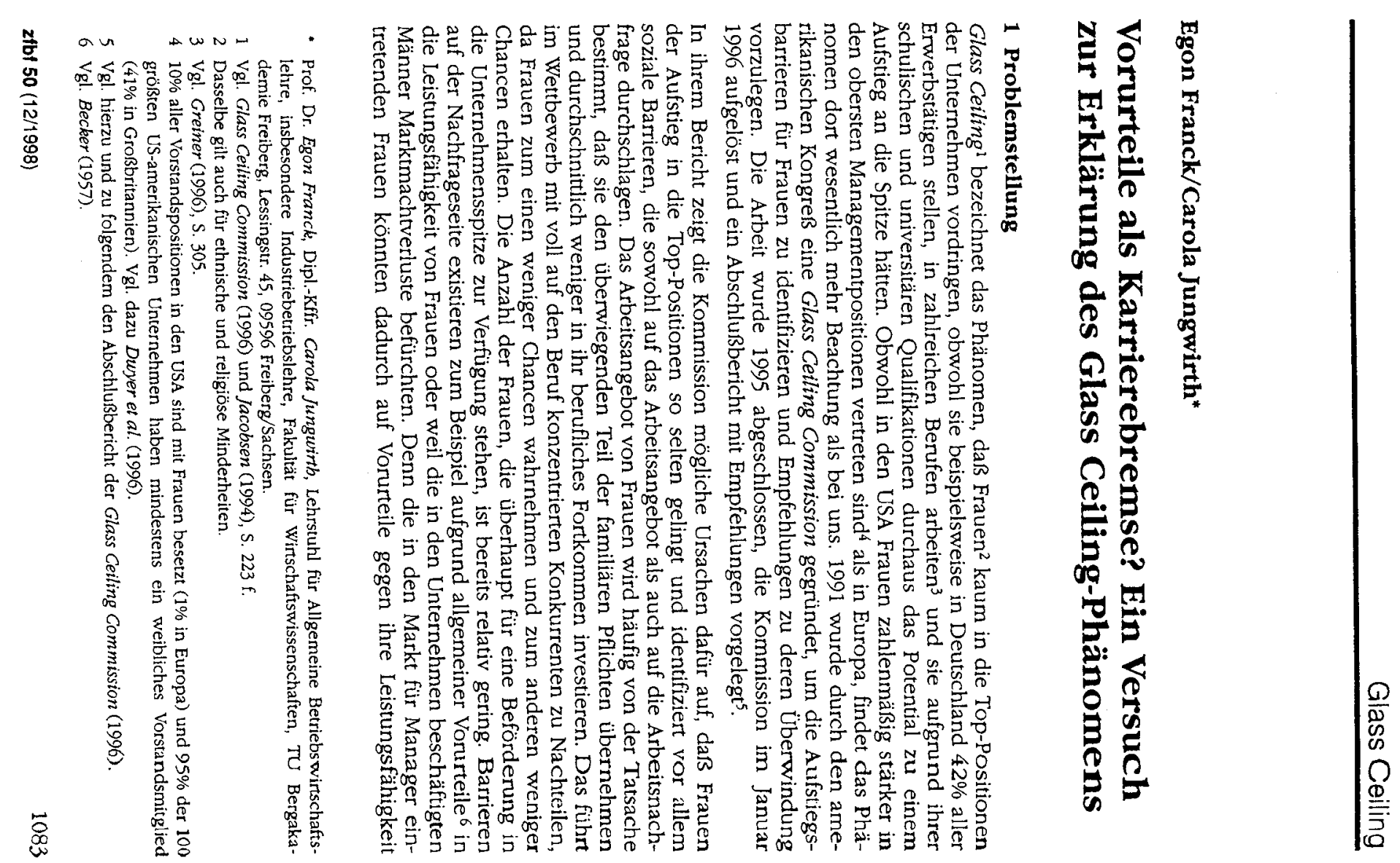


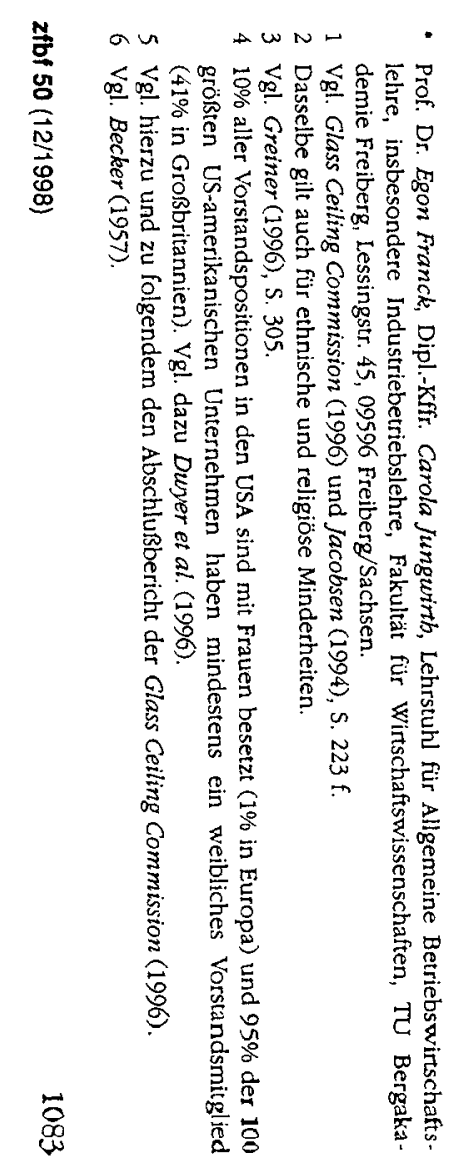

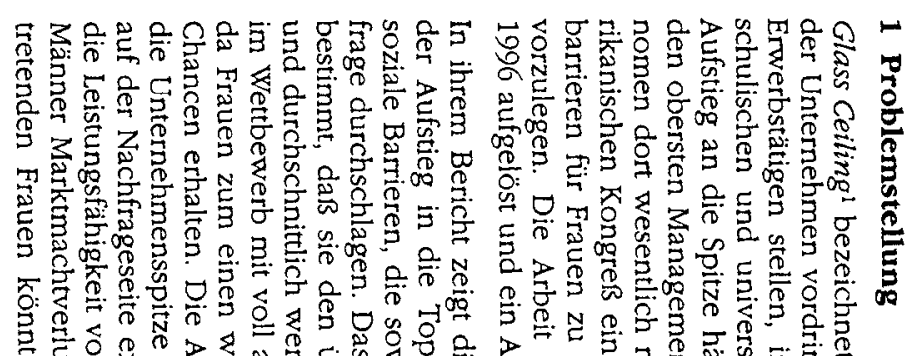

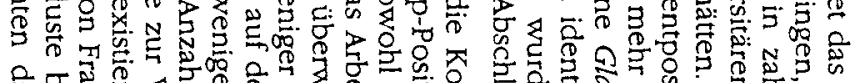

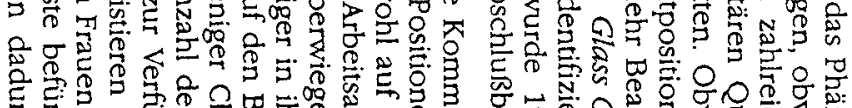

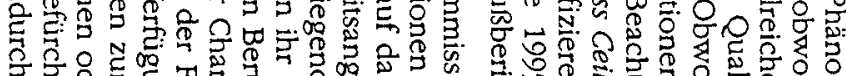

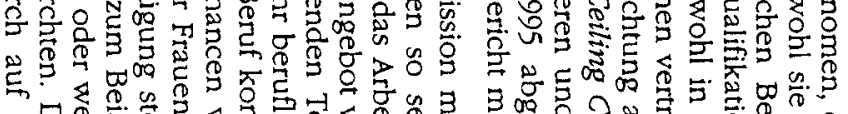

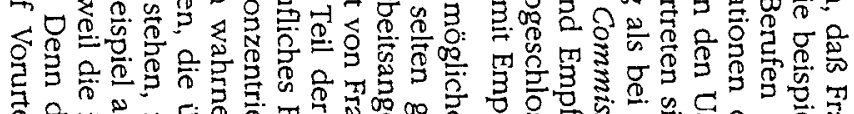

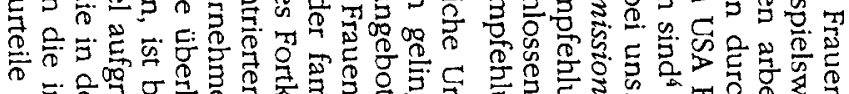

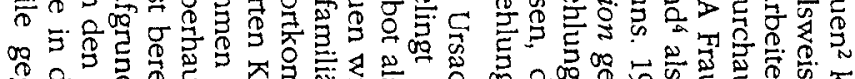
o

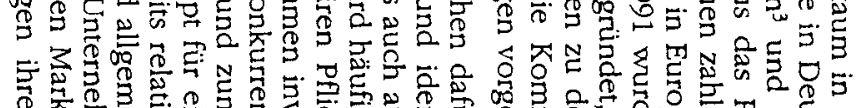
6

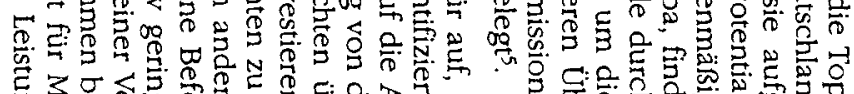

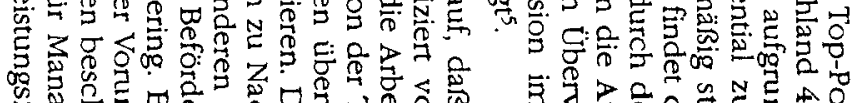

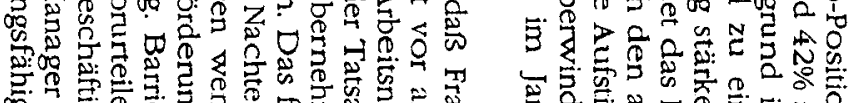

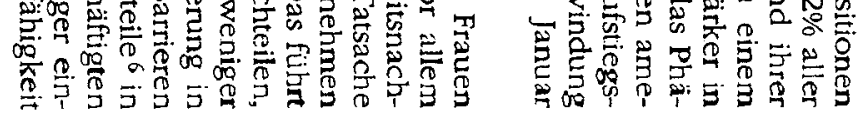

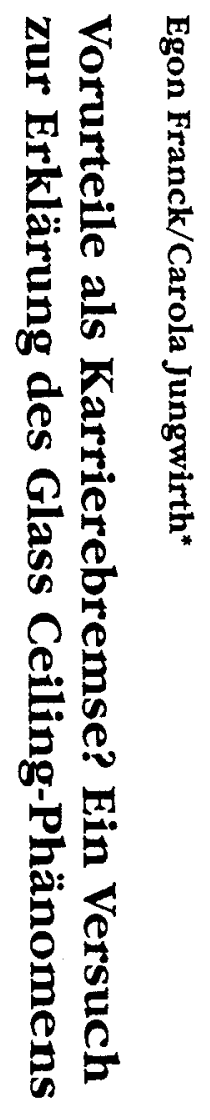



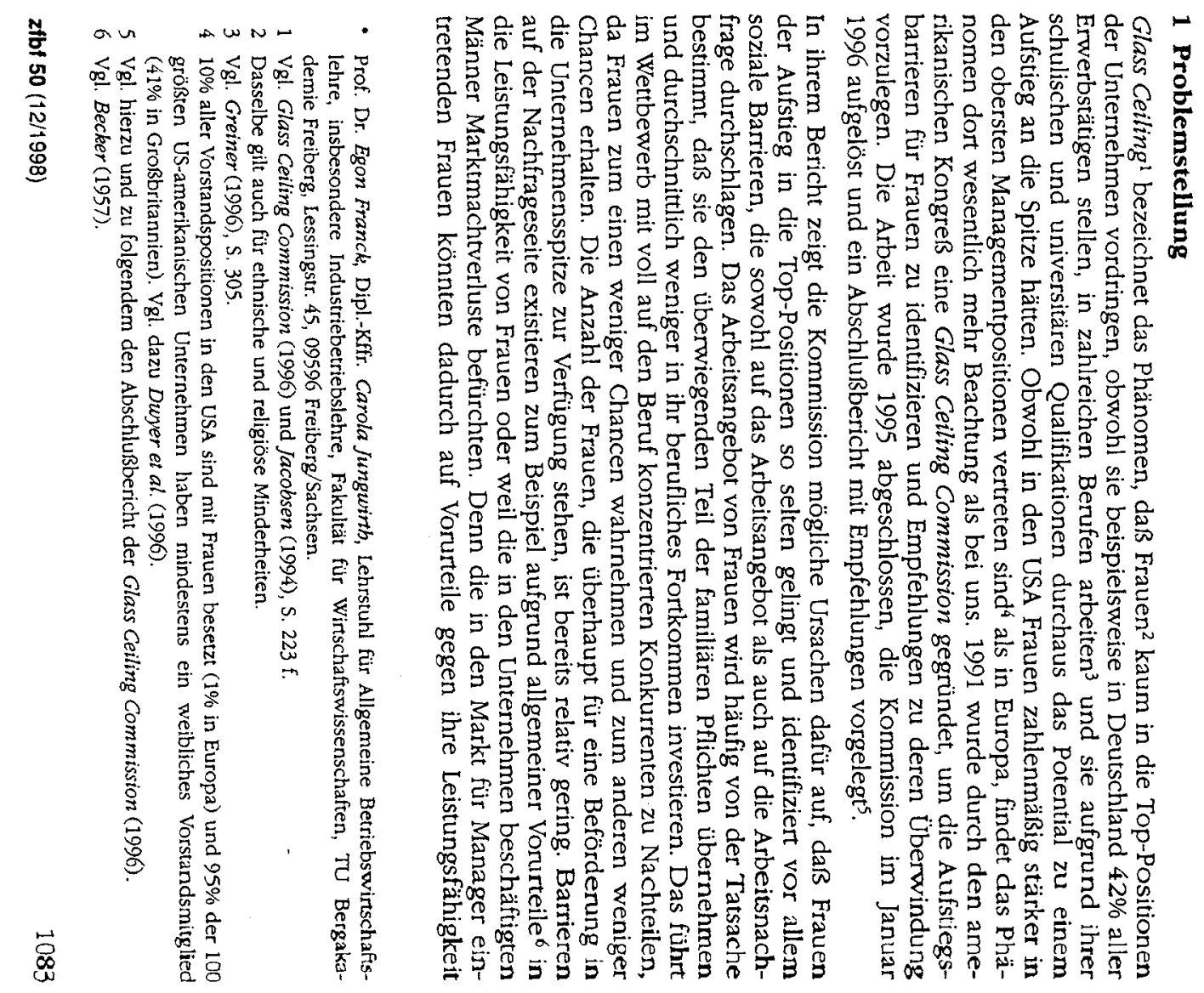

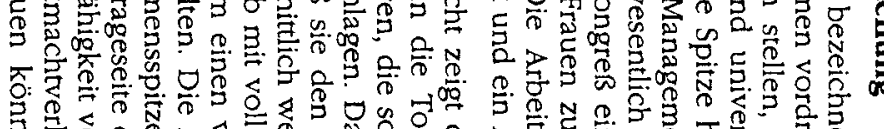

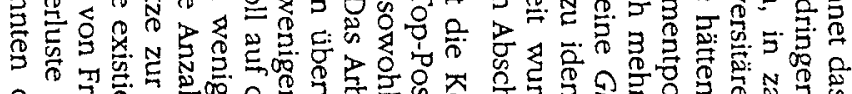

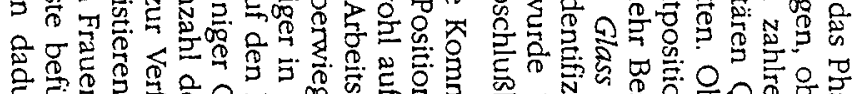

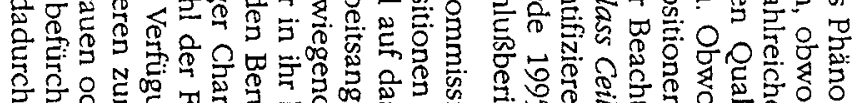

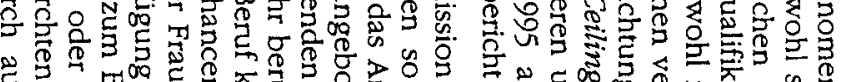

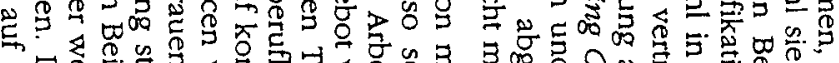

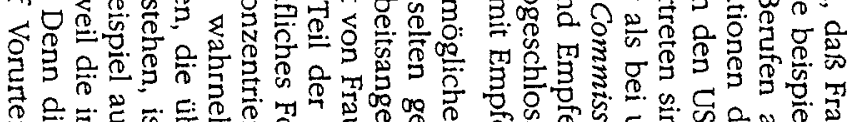

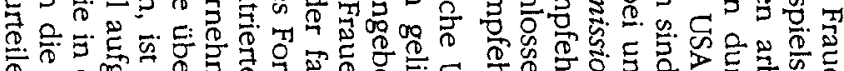

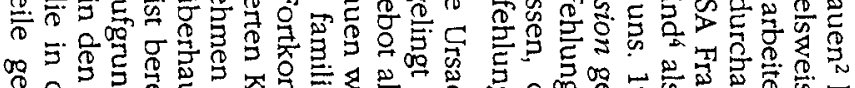

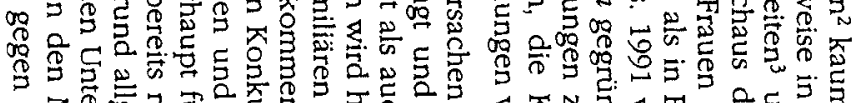

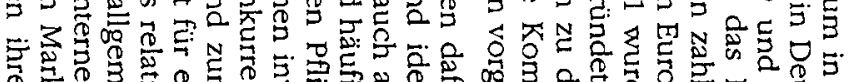

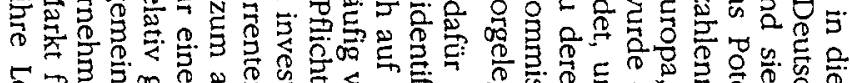

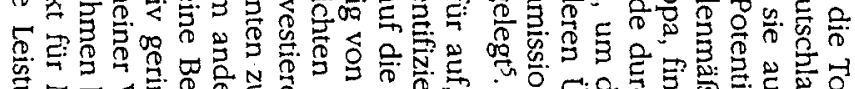

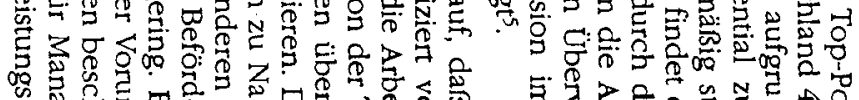

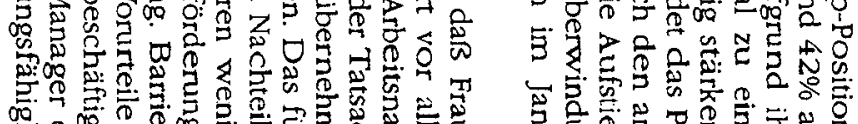

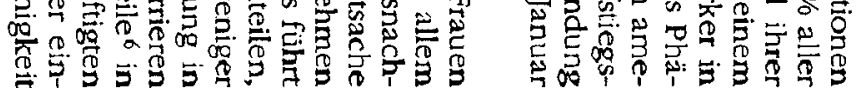

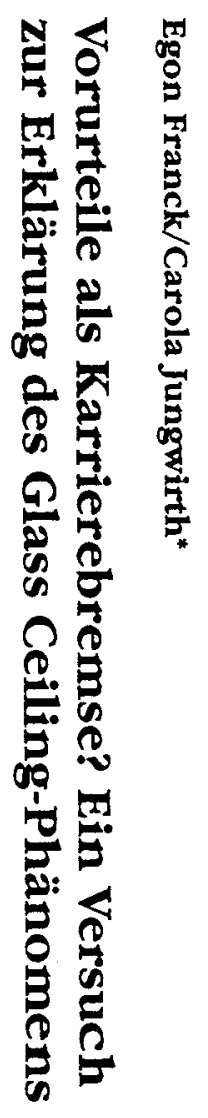




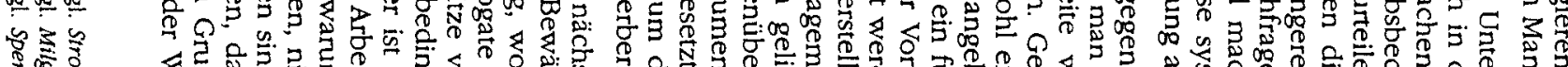

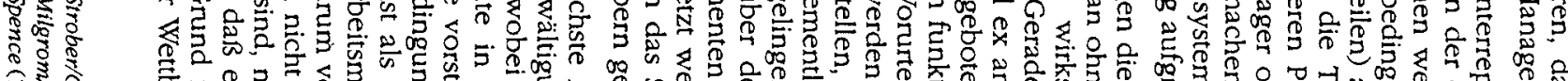

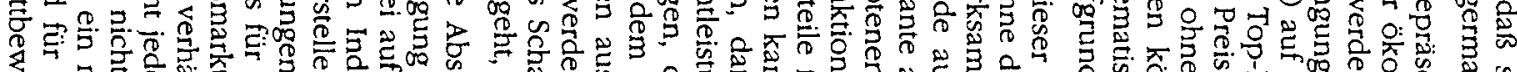

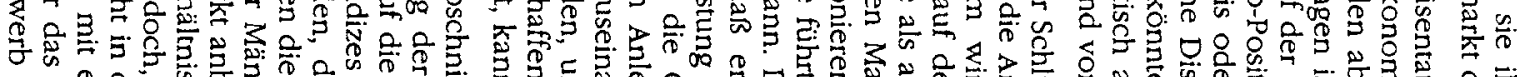

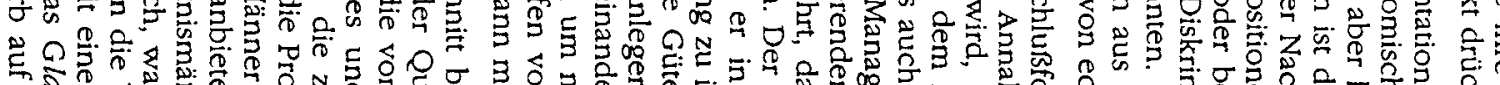

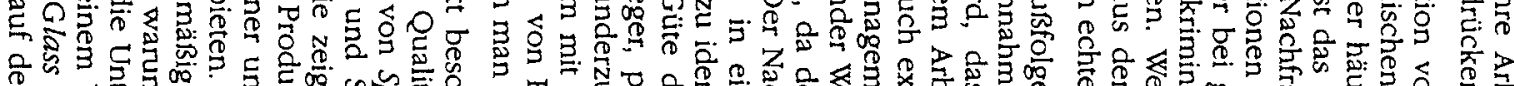

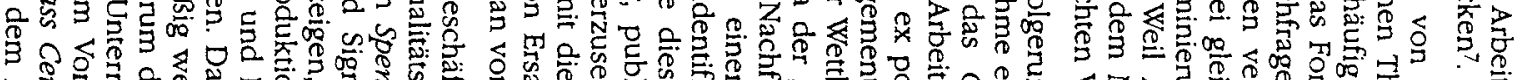

$\rightarrow$ 至

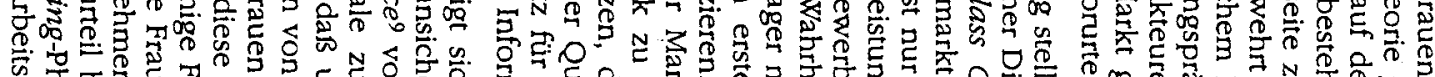

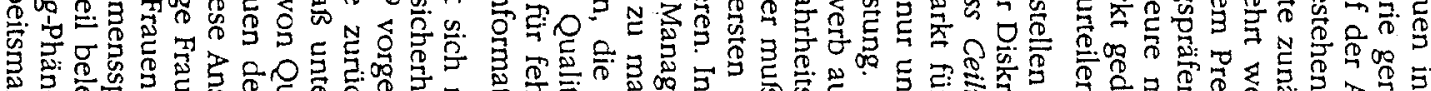

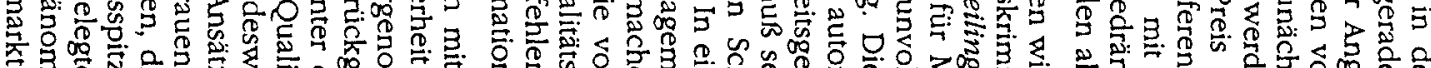

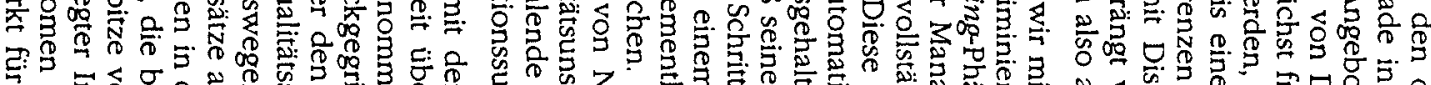

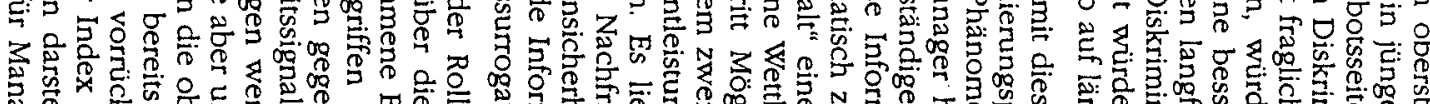

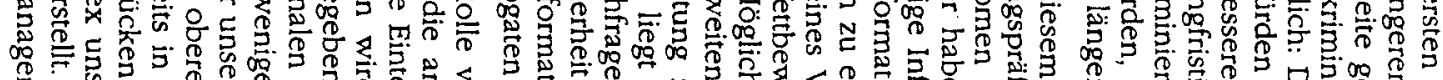

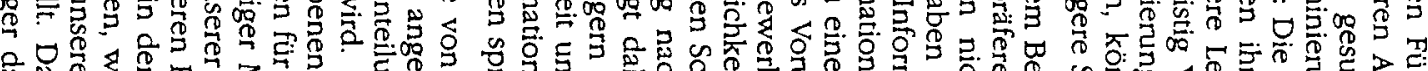

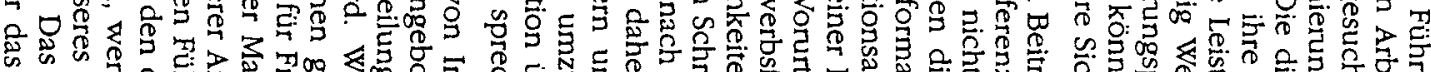

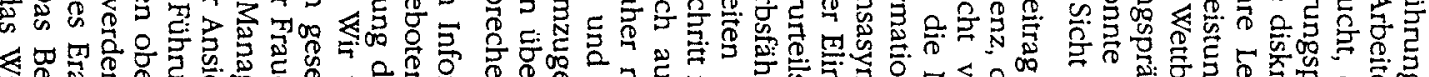

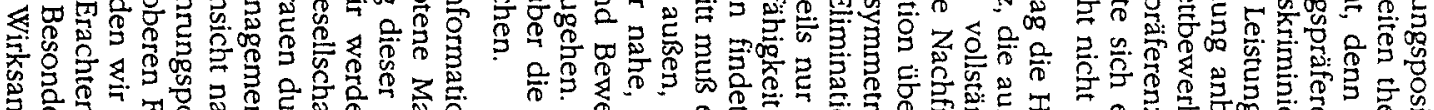

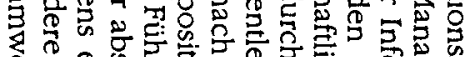

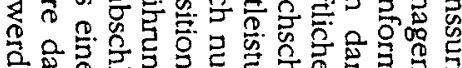

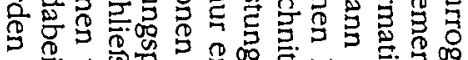

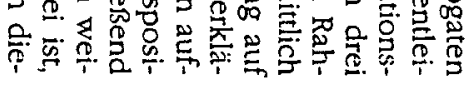

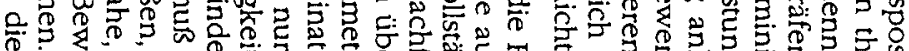

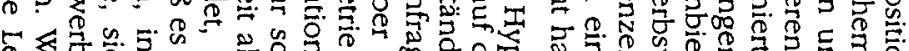

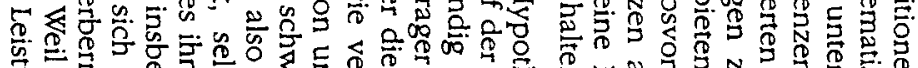

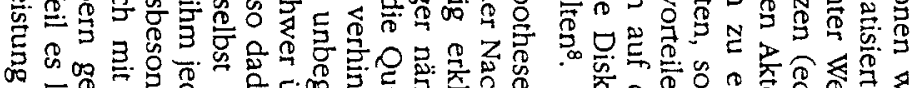
중.

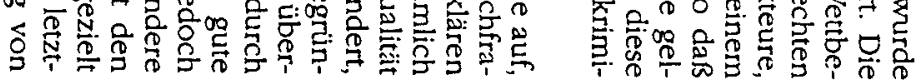

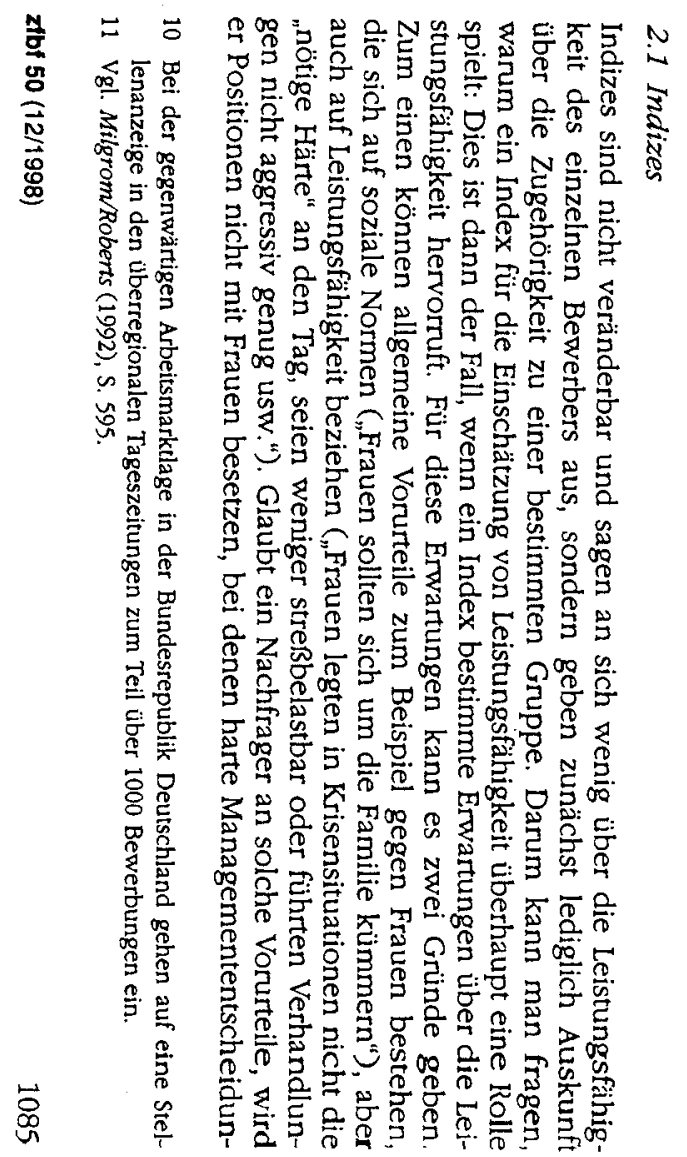

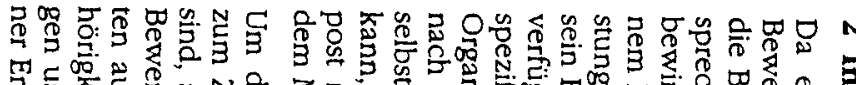

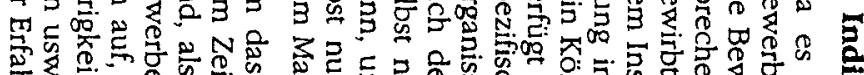

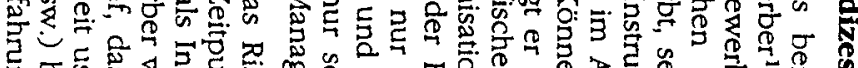

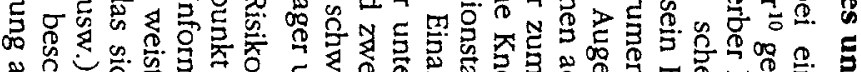

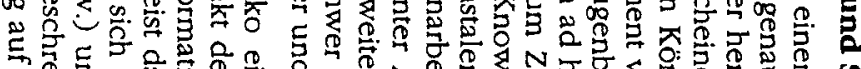

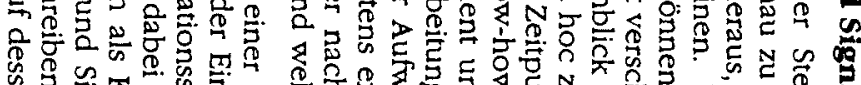

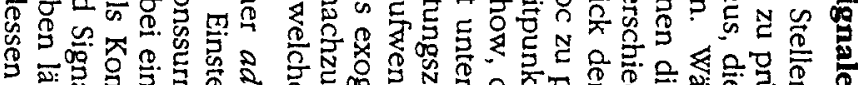

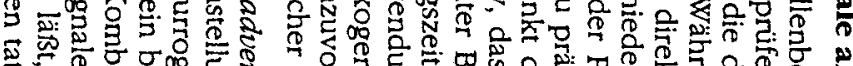

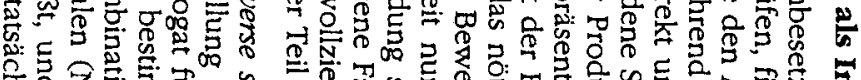

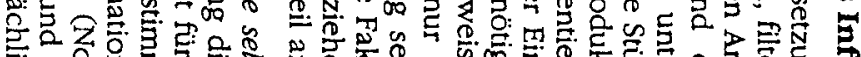

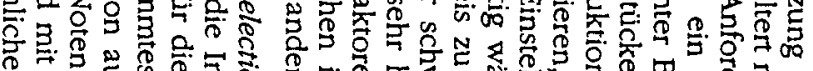

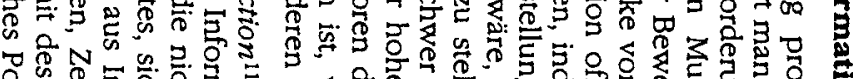

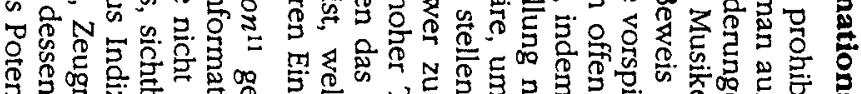

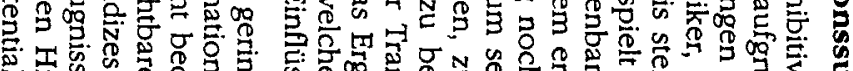

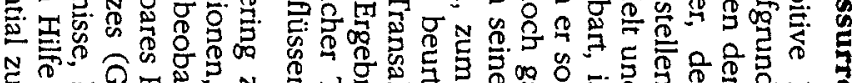

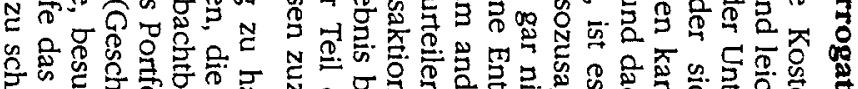

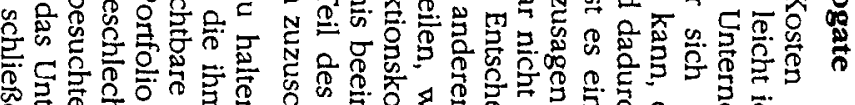

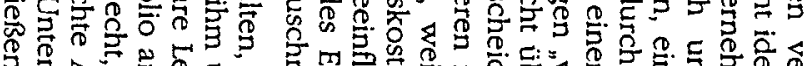

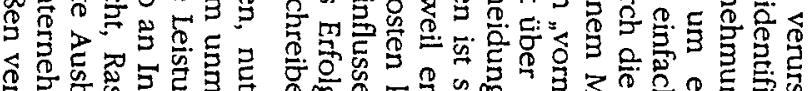

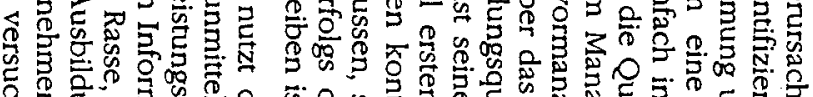

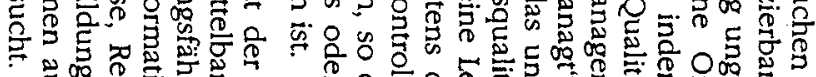

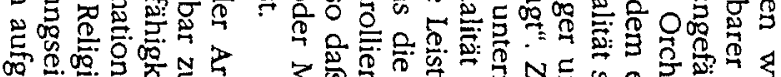

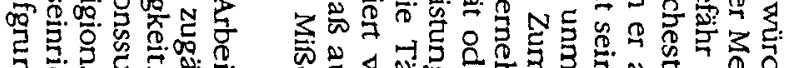

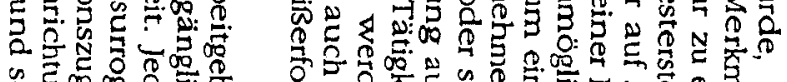

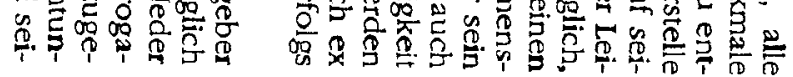

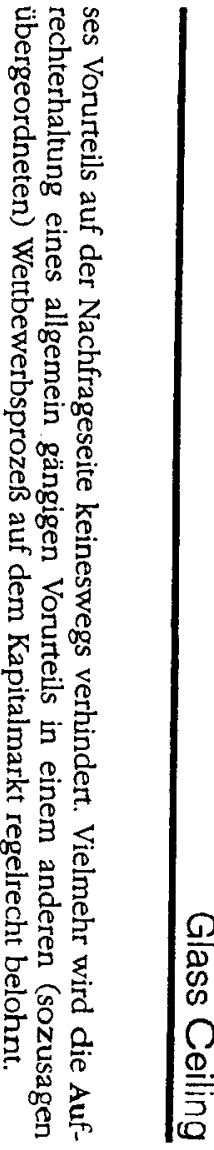




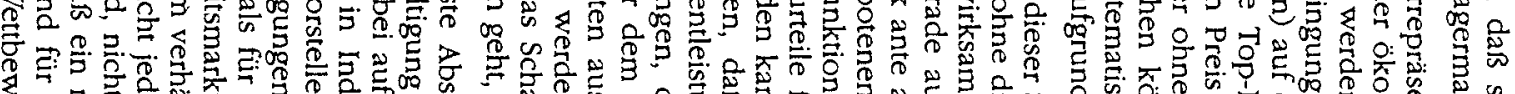

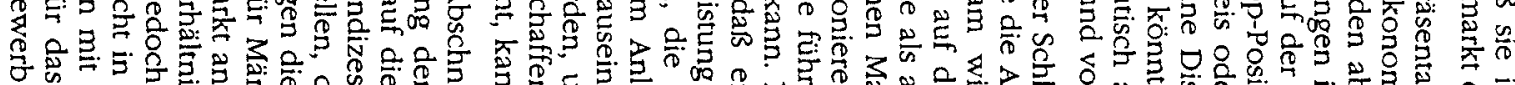

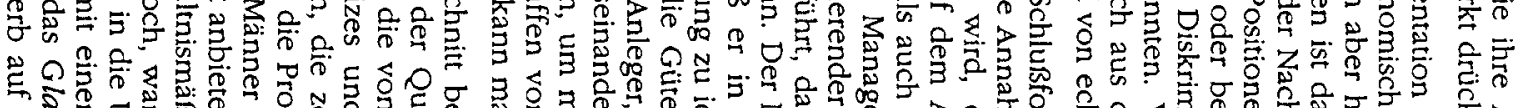

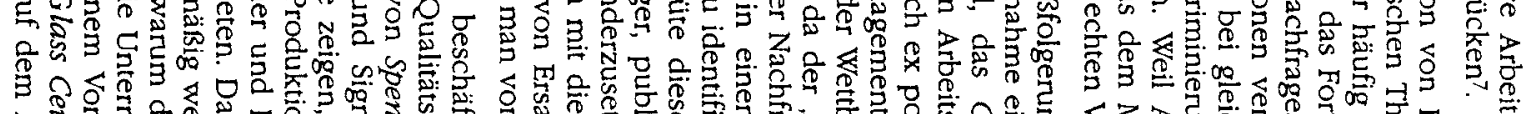

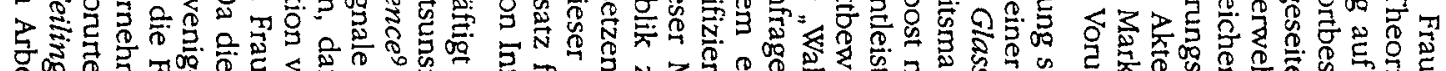

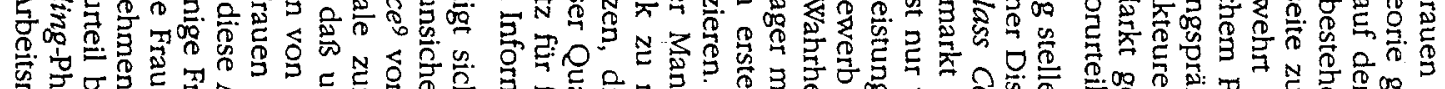

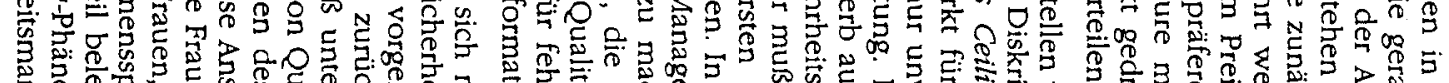

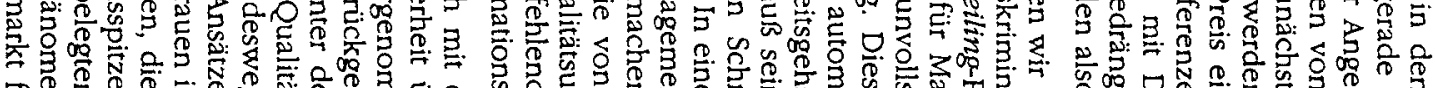

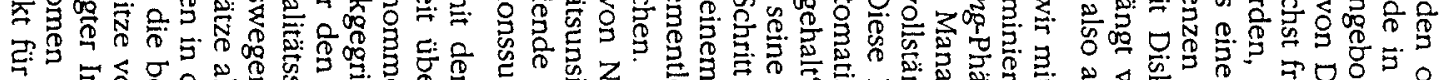

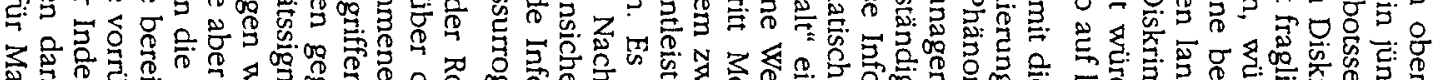

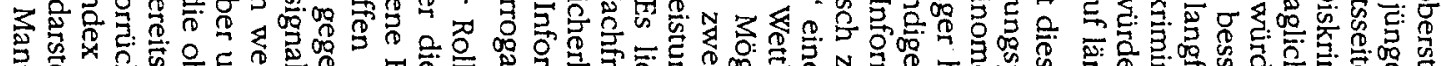

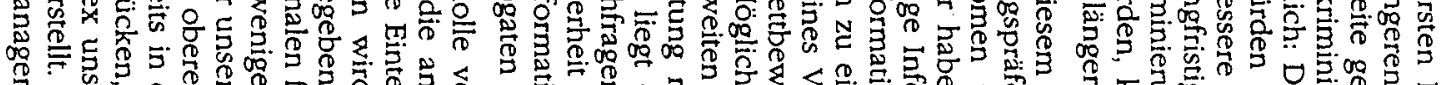

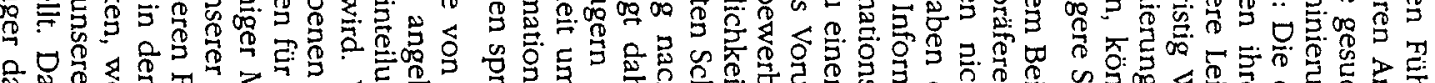

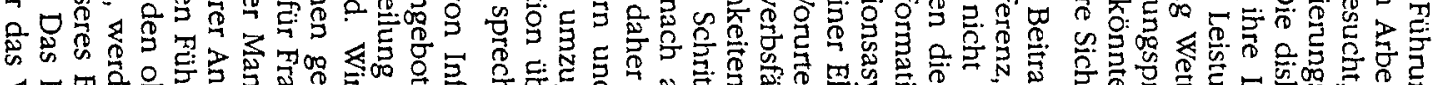

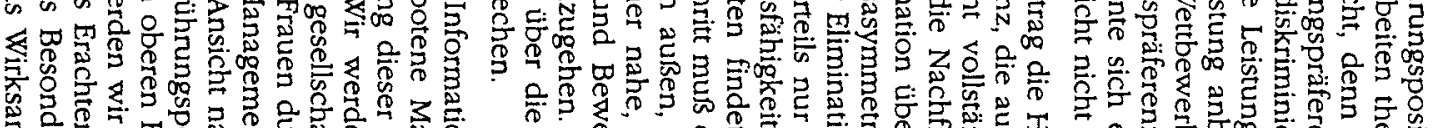

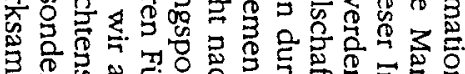

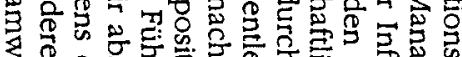

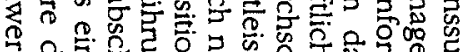

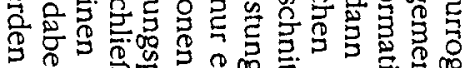

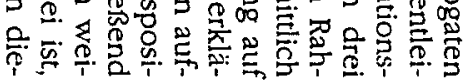

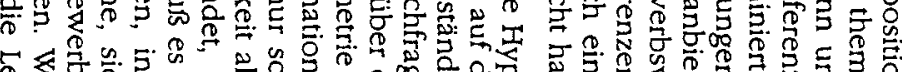

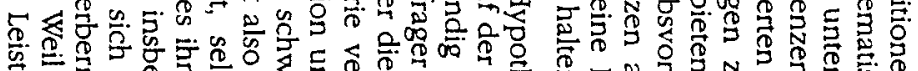

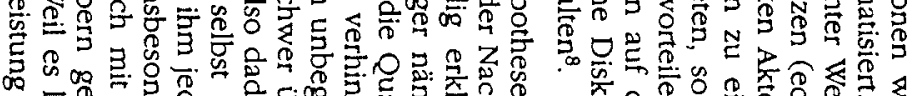

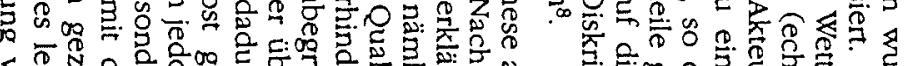

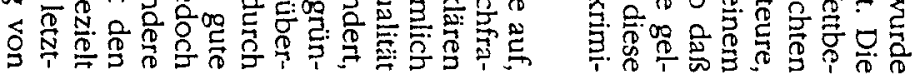

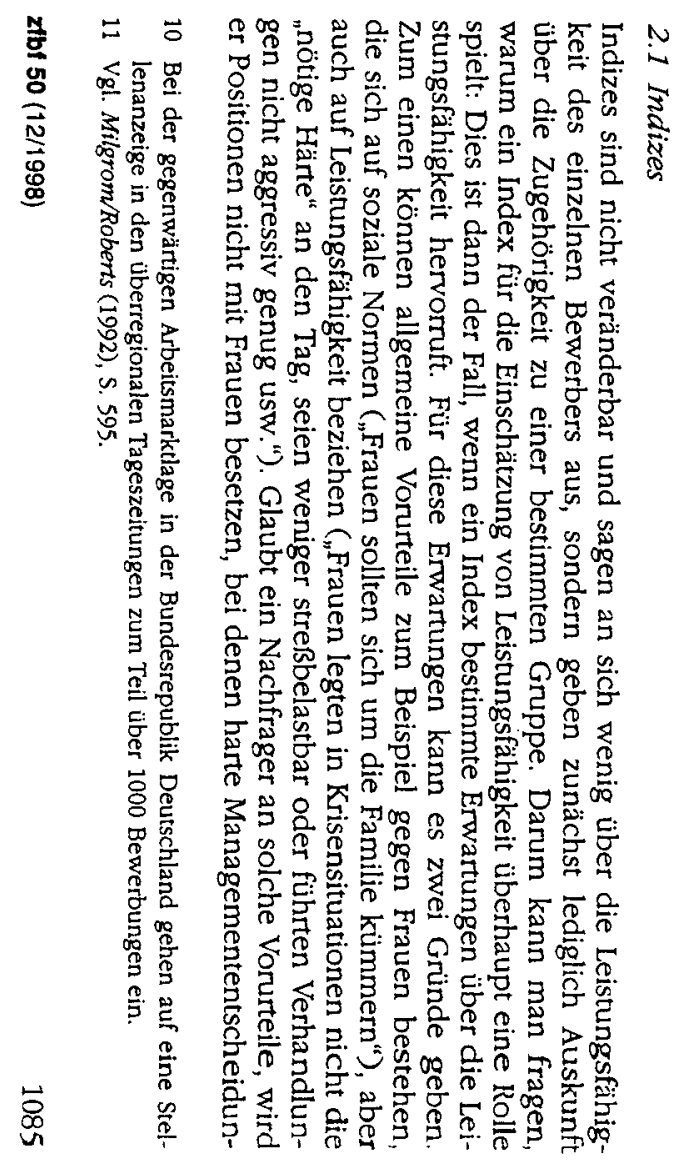

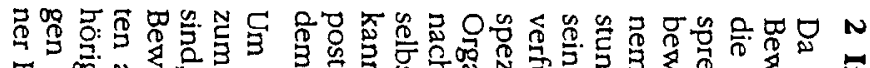

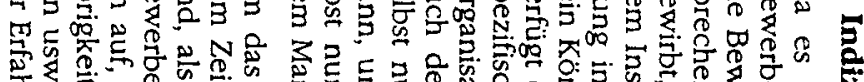

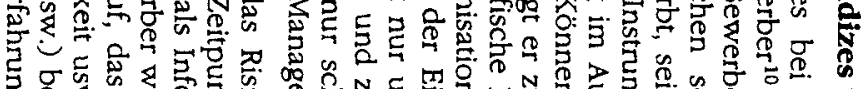

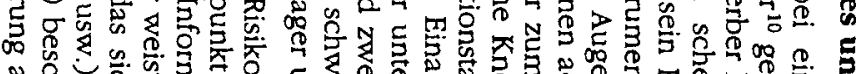

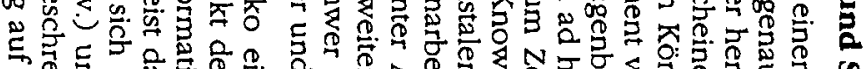

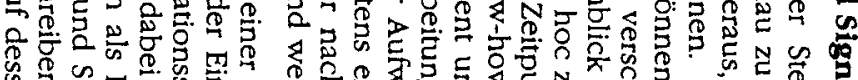

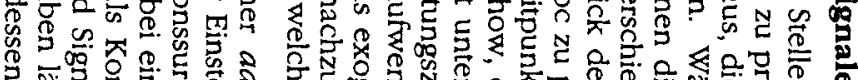

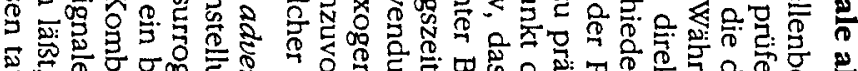

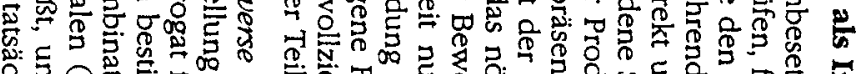

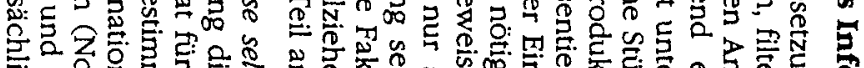

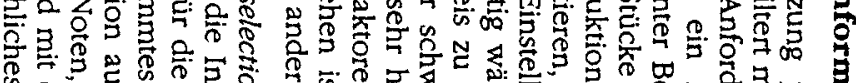

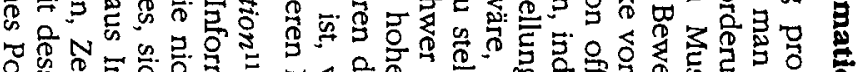

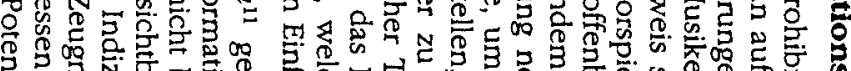

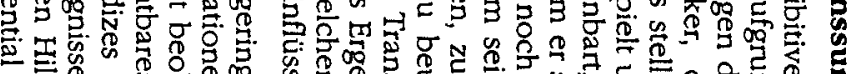

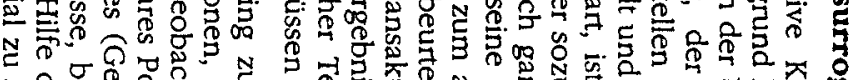

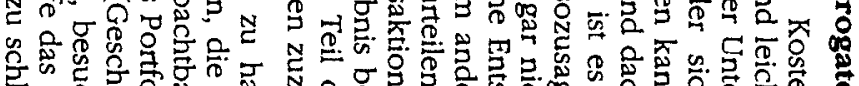

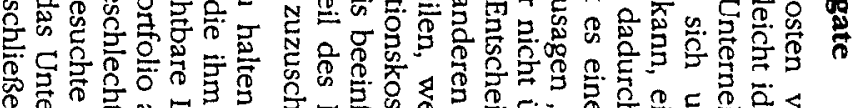

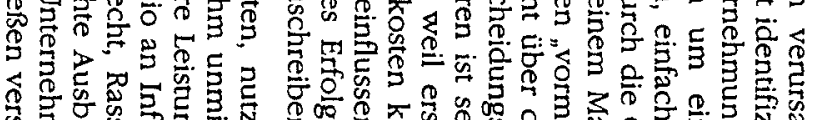

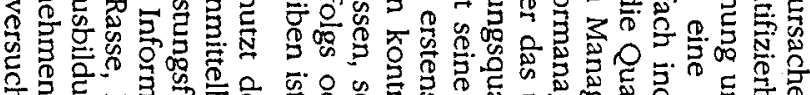

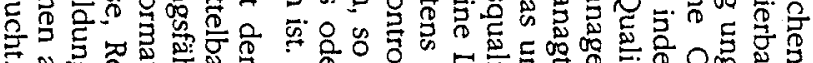

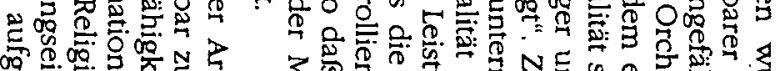

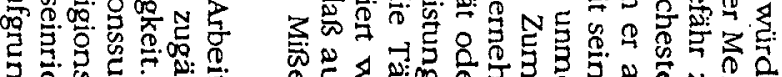

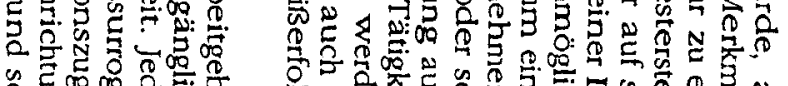

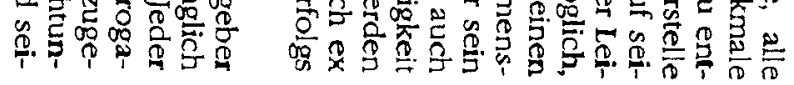

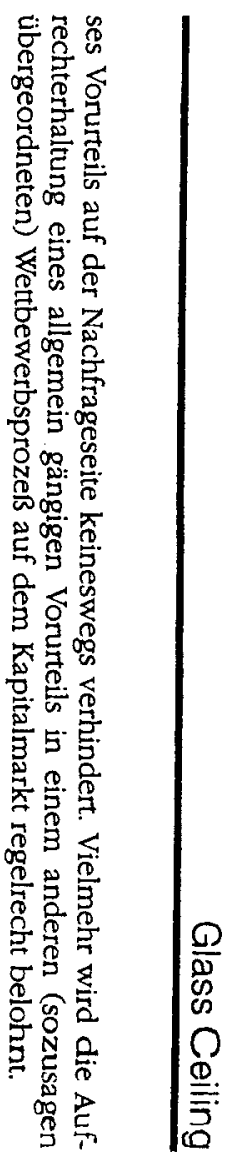




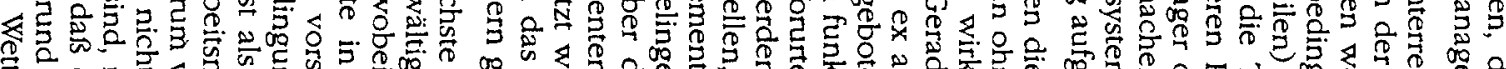

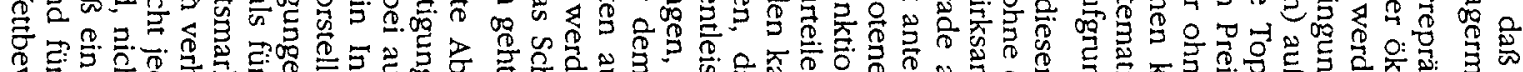

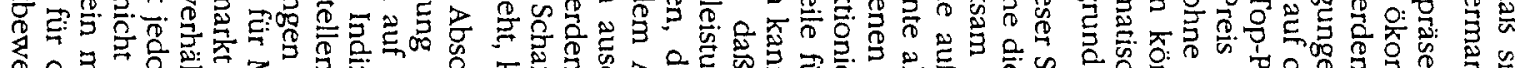

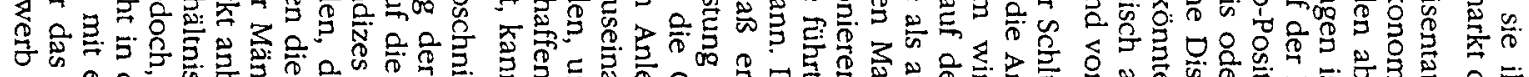

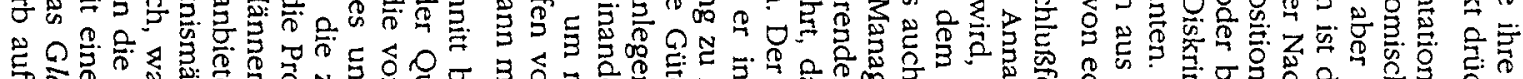

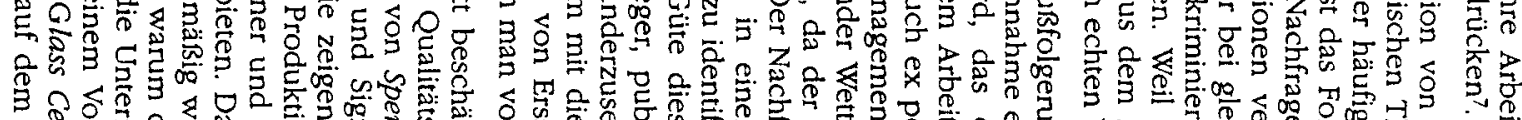

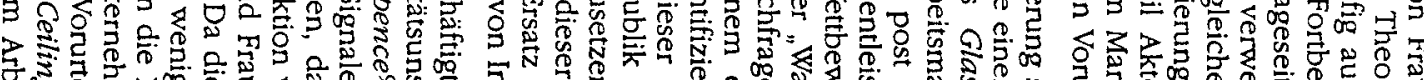

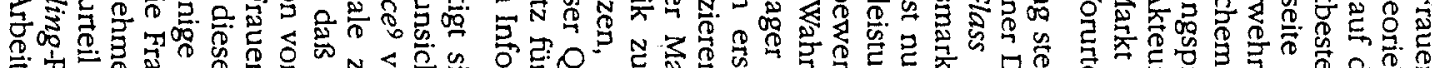

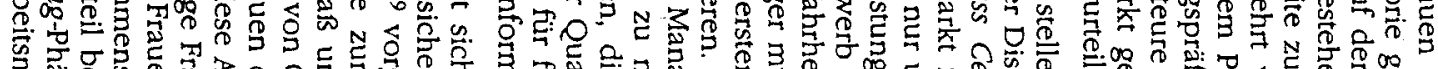

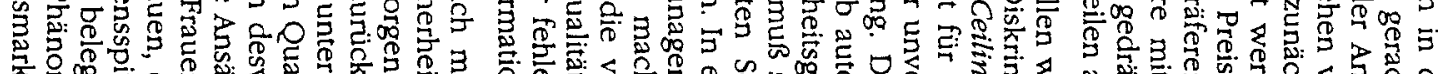

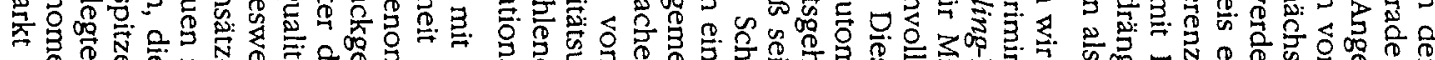

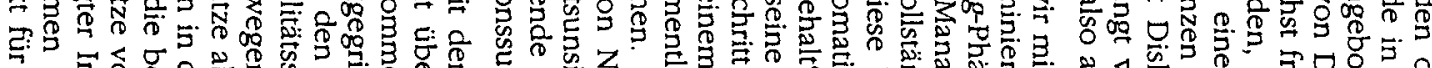

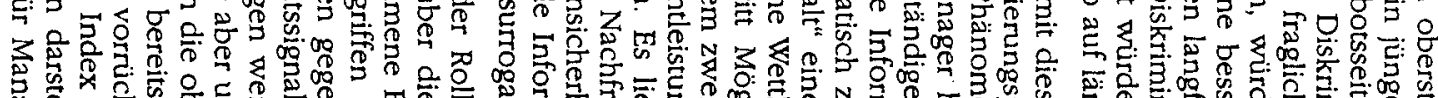

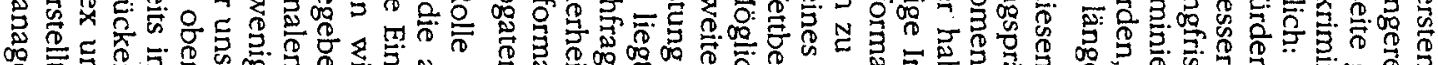

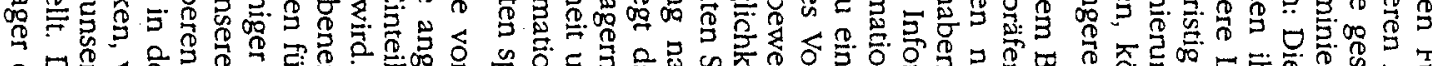

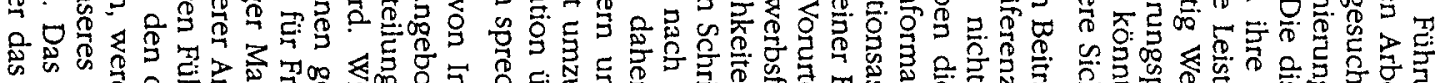

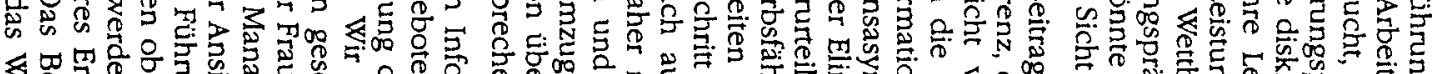

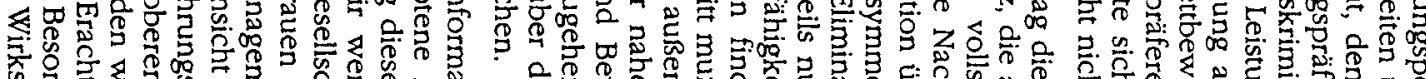

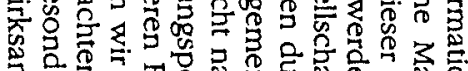

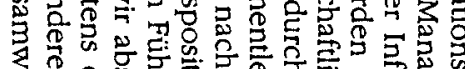

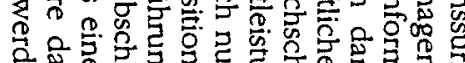

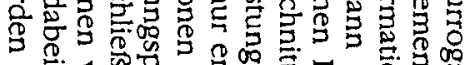

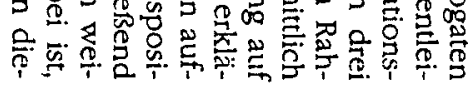

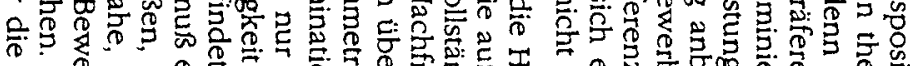

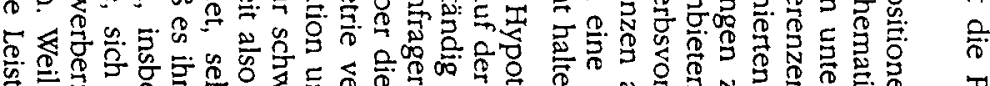

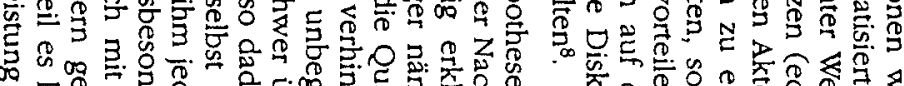
吉

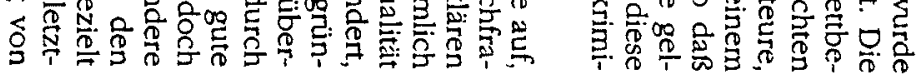

$=$

赵 $\overline{3}$

然

की

实

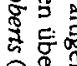

客梁

过

in

要

政

芴

क्ष马ㅇ

录产

볼

용

흥

幽

票萼

器照

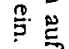

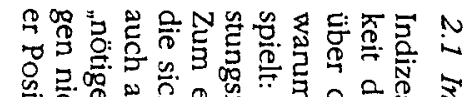

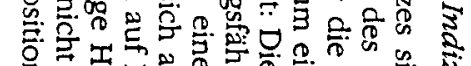

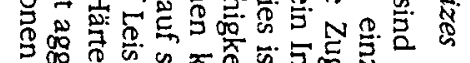
然:

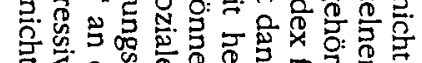

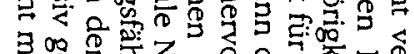
打 品

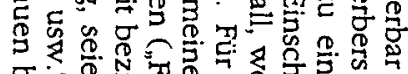
讨

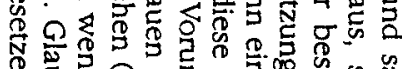

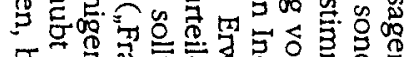
‥ ․ㅗㄴ 0 중 要

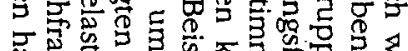

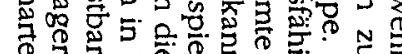
궁 5 웅 की o 3 들

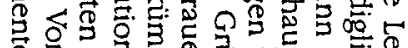

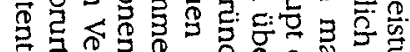

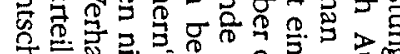
然.

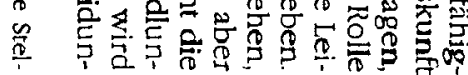

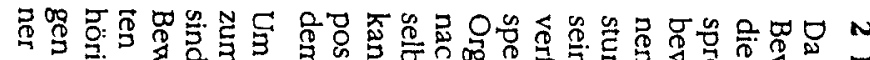

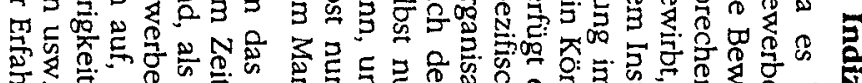

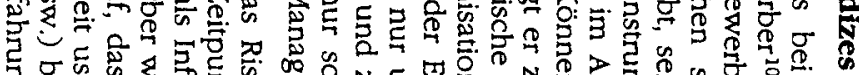

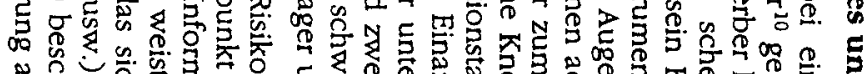

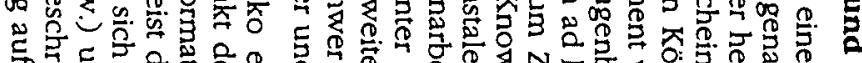

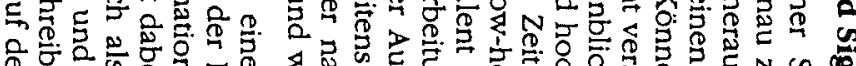

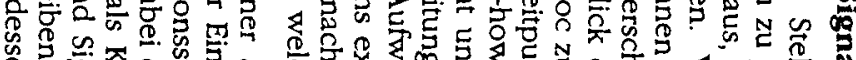

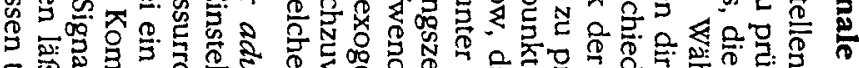

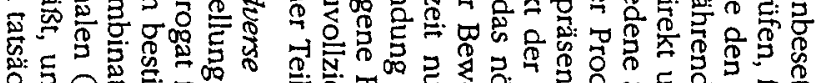

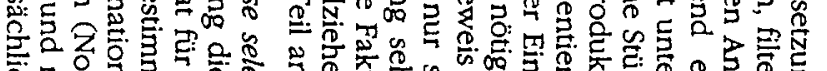

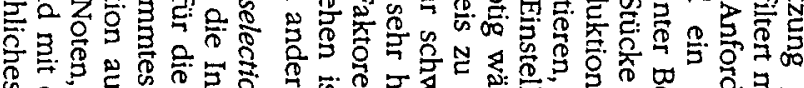
保N N

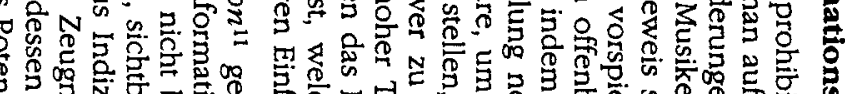

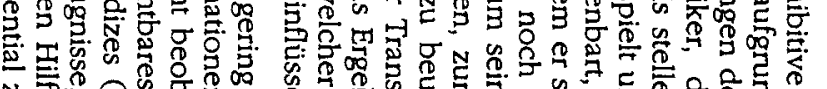

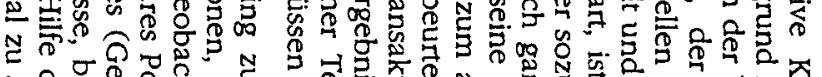

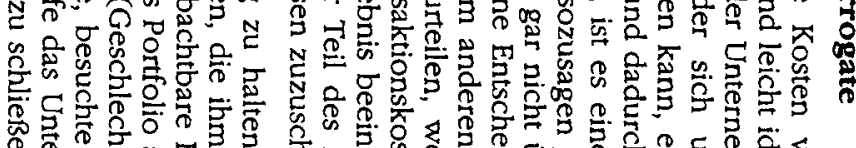

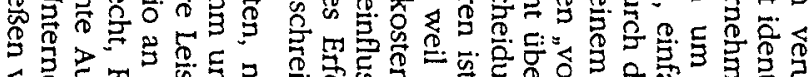

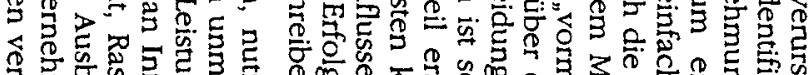

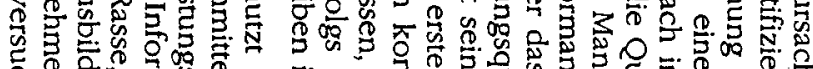

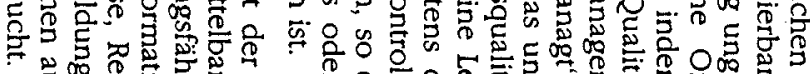

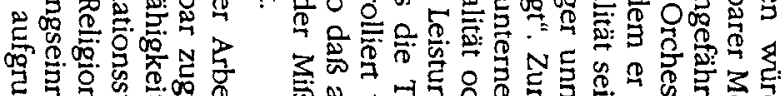

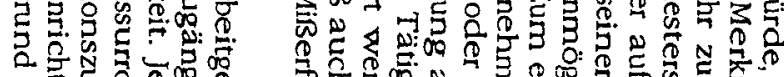

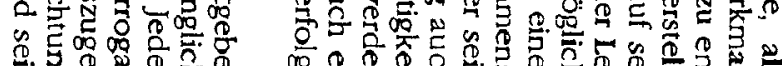

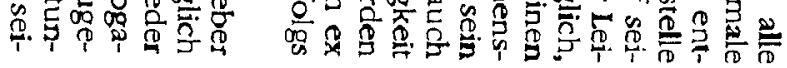

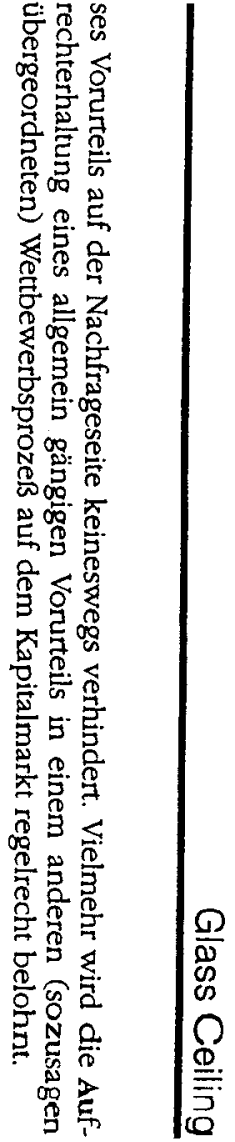




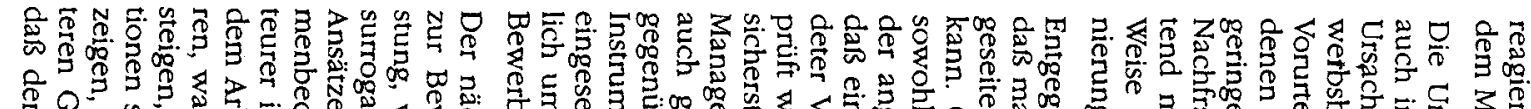

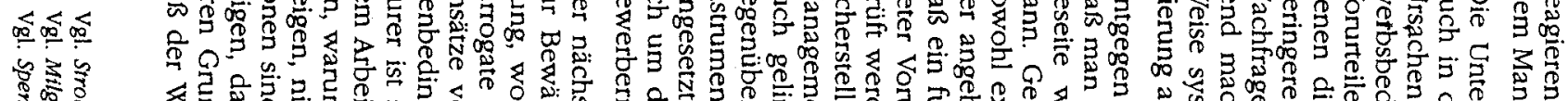

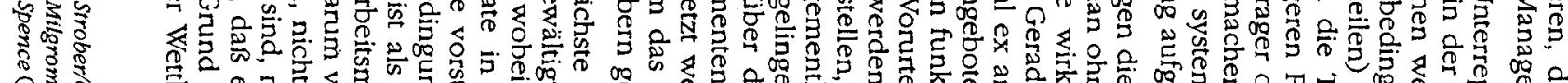

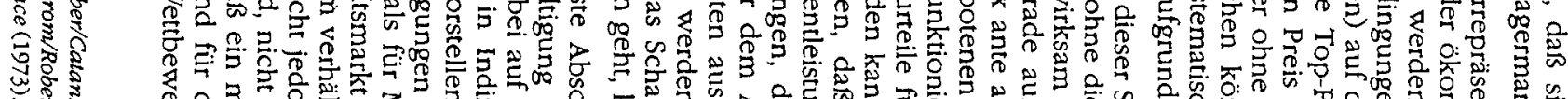

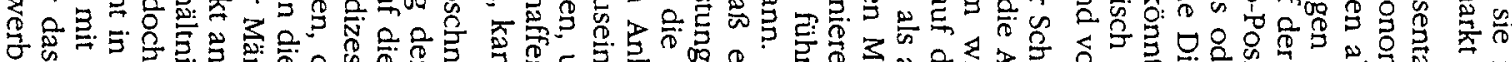

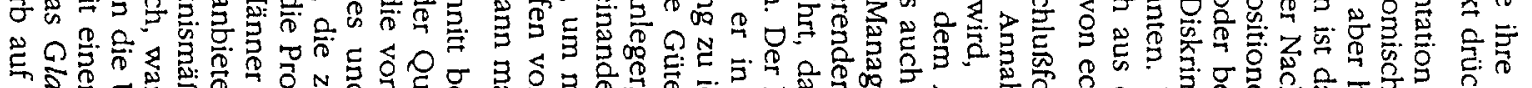

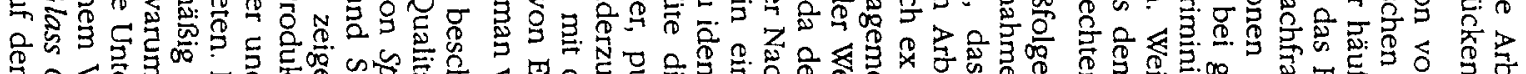

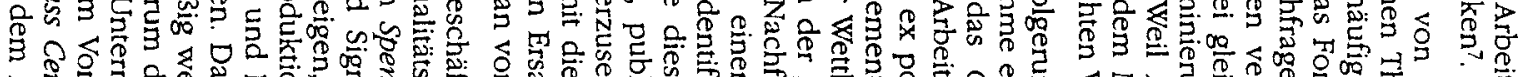

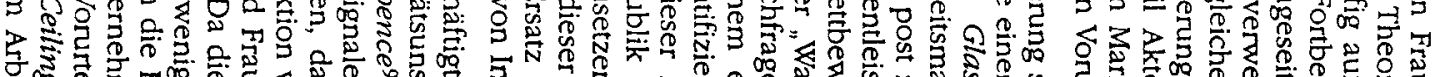

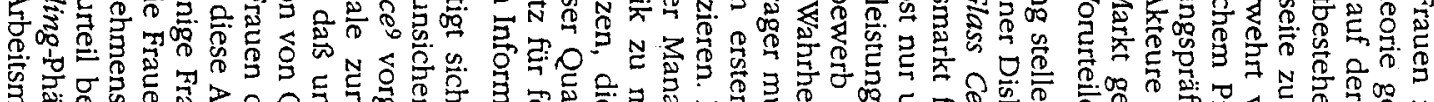

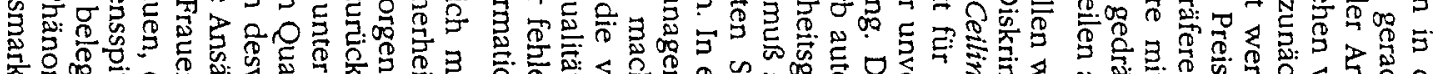

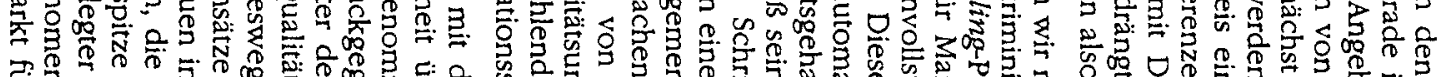

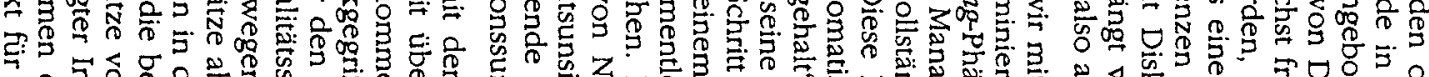

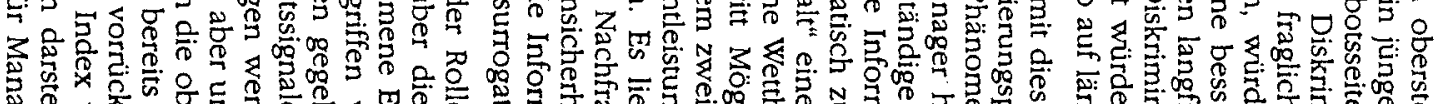

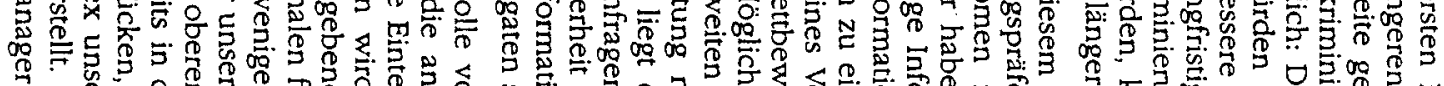

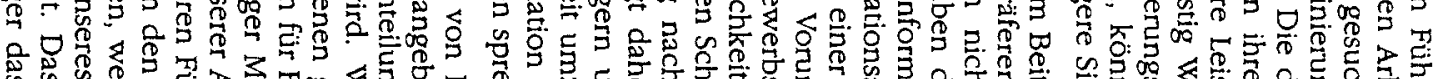

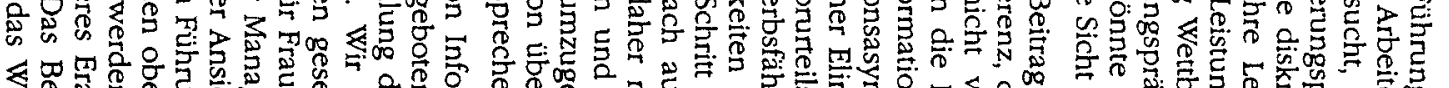

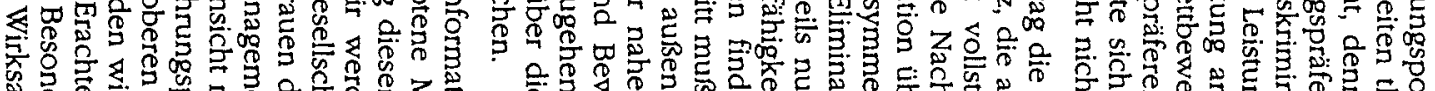

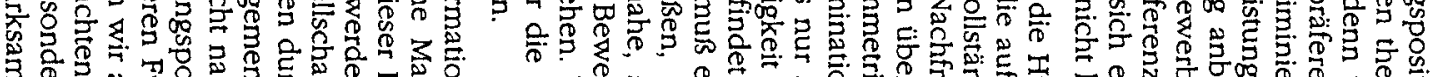

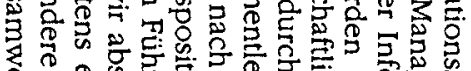

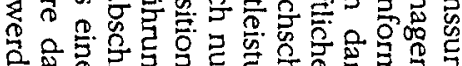

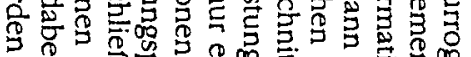

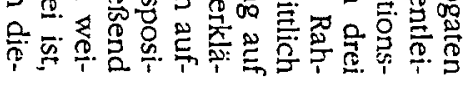

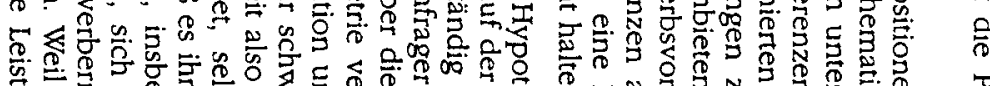

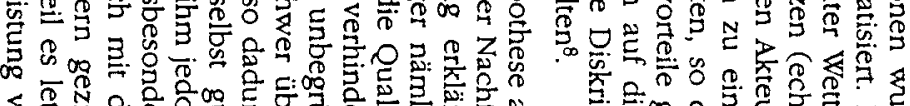

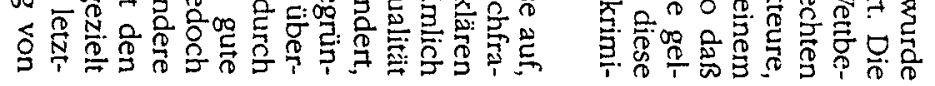

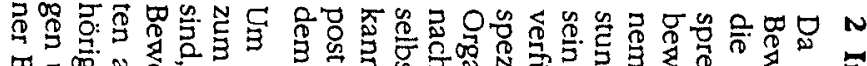

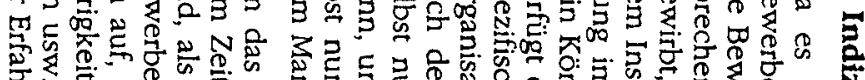

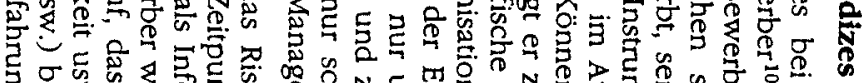

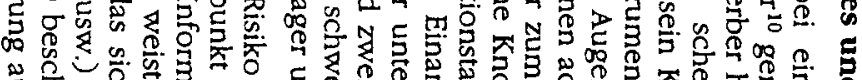

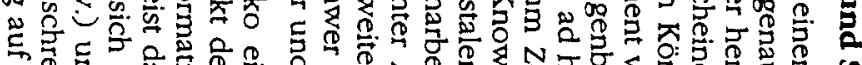

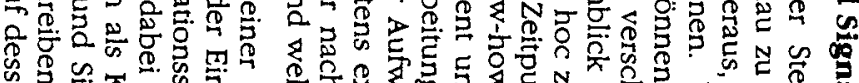

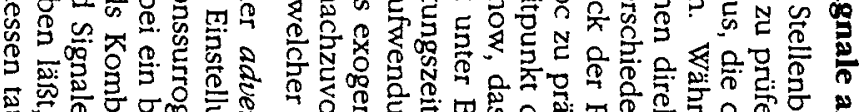

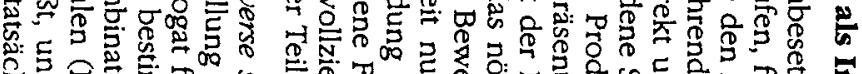

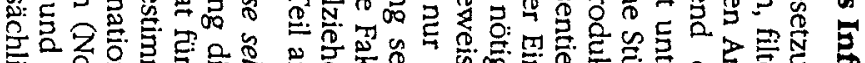

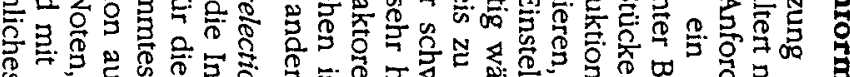

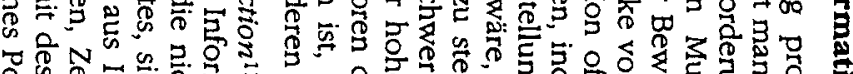

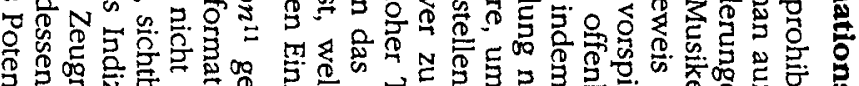

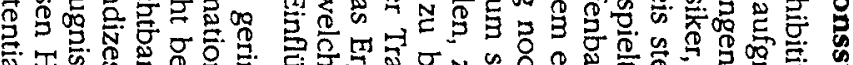

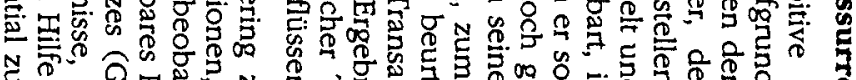

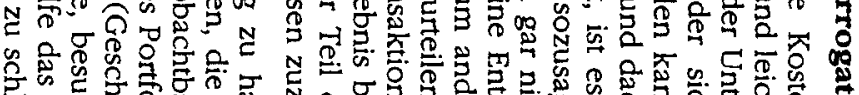

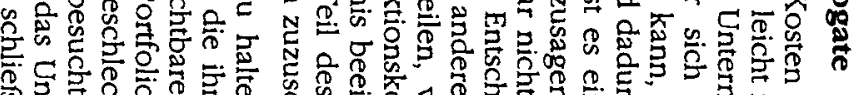

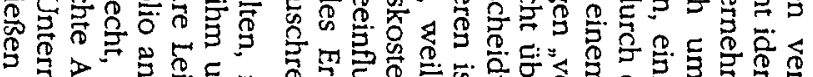

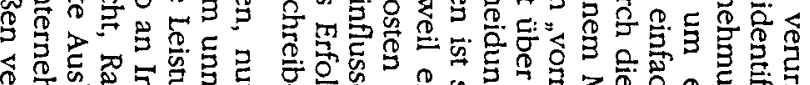

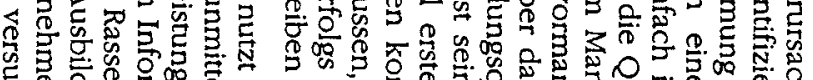

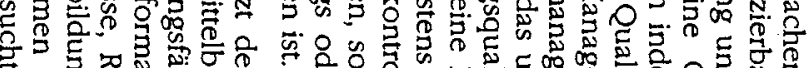
纯

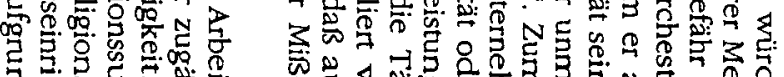

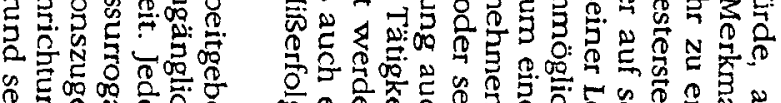

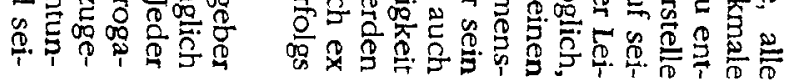

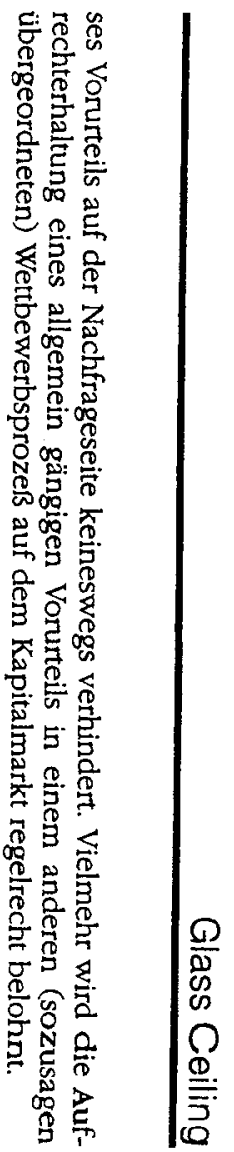




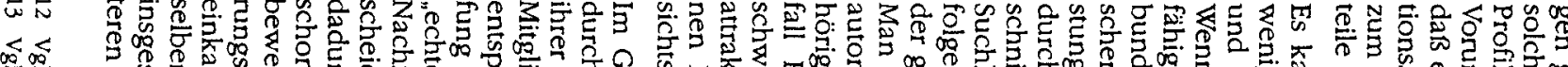

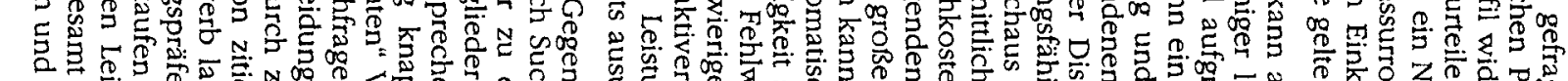

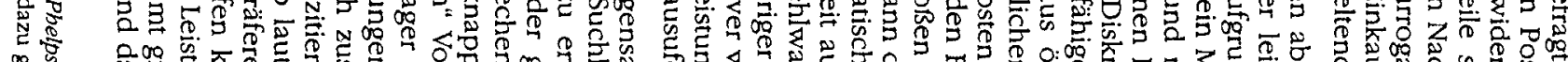

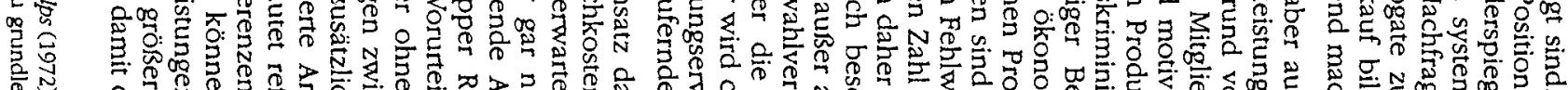

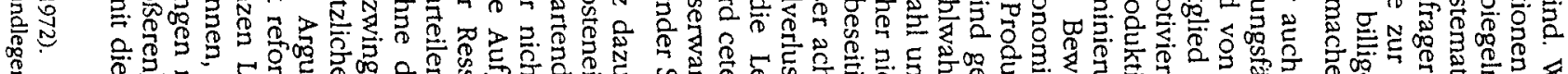

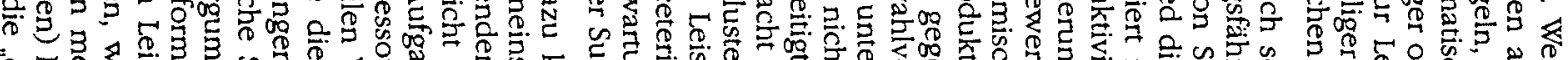

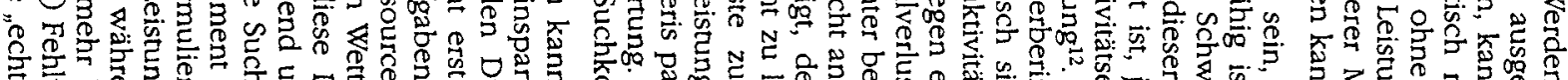

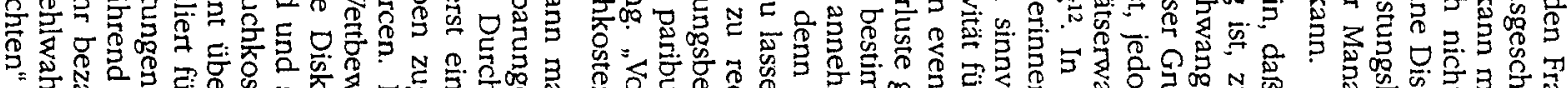

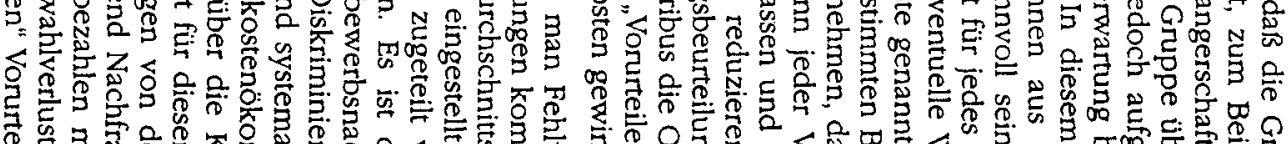

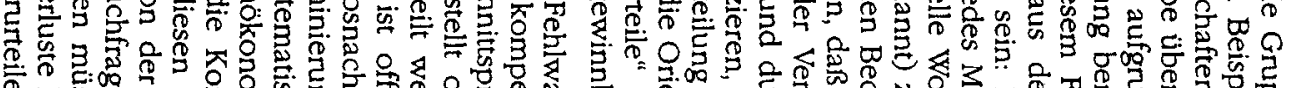

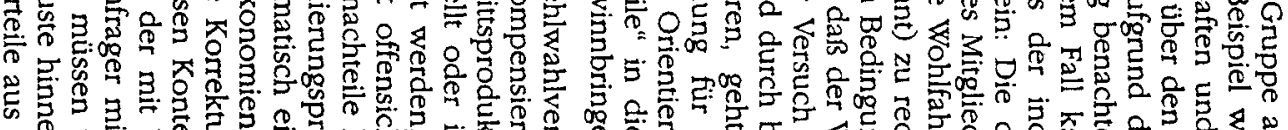

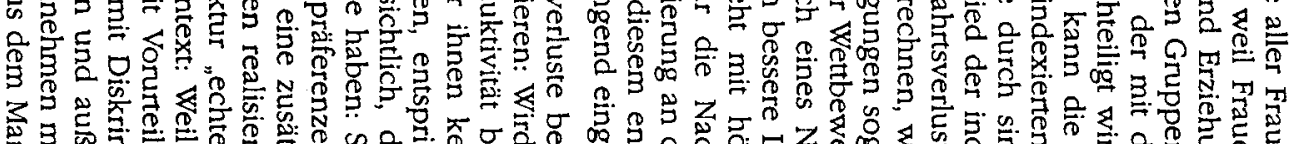

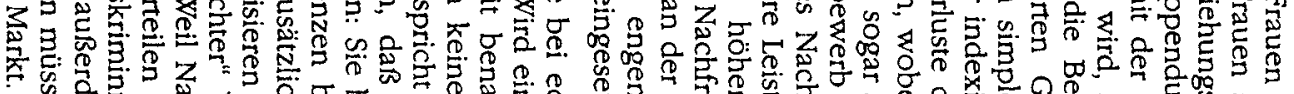

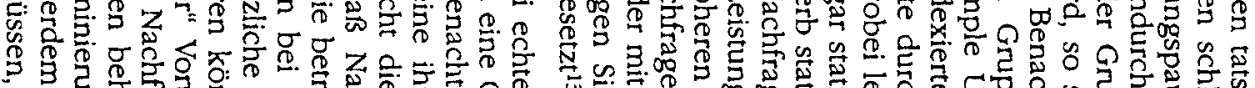

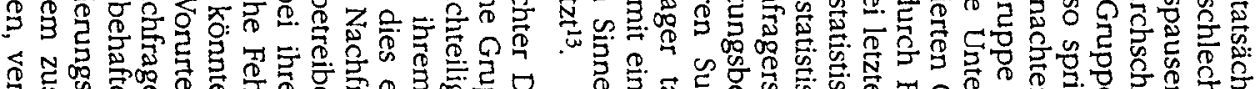

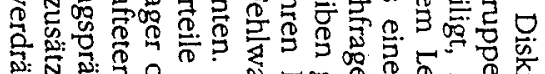

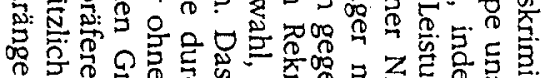

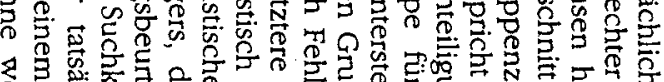

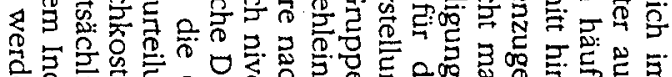

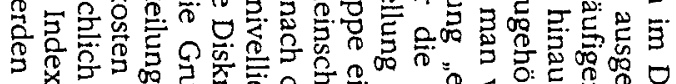

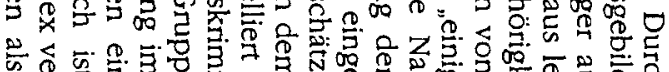
ㄴ. 숭

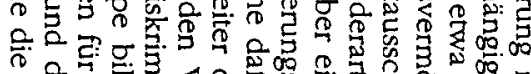

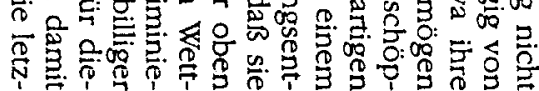

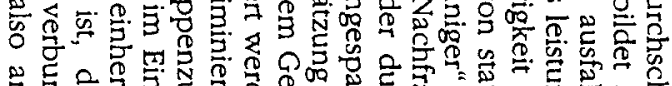

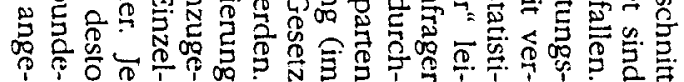

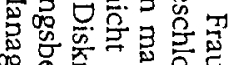

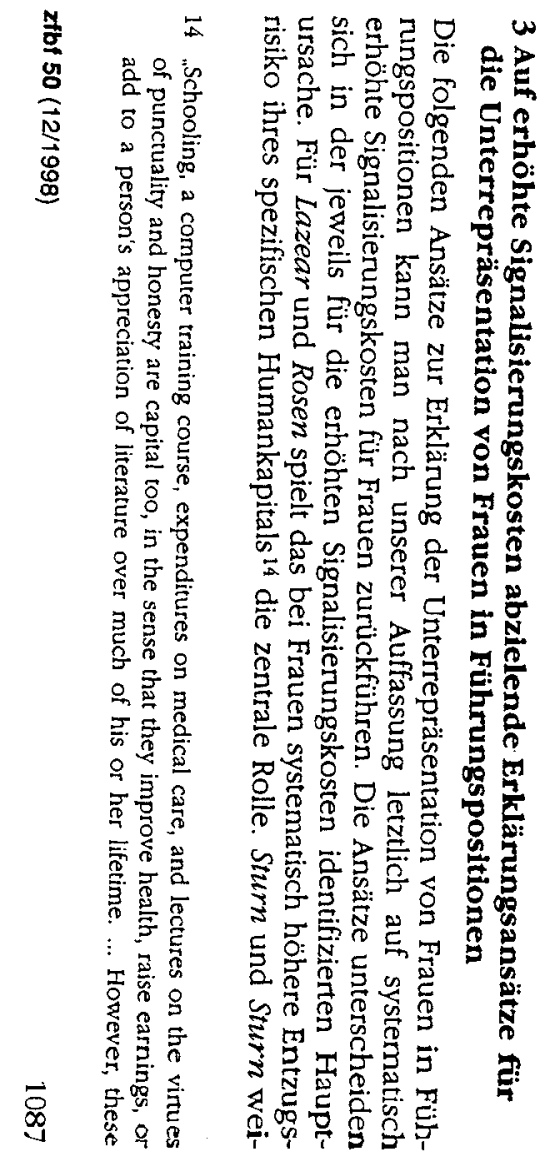

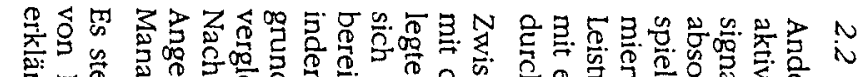

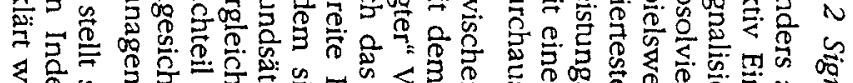

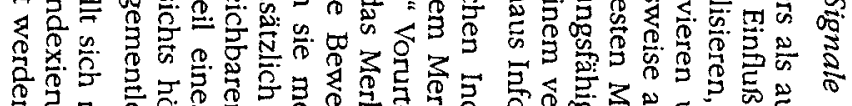

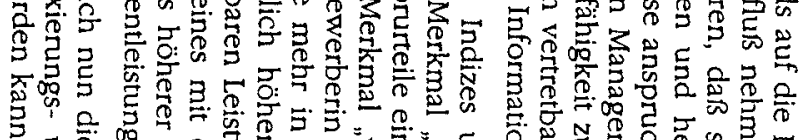
5 言

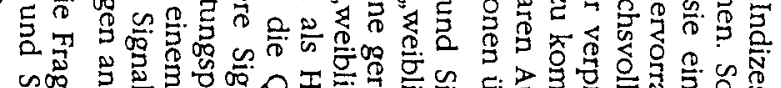

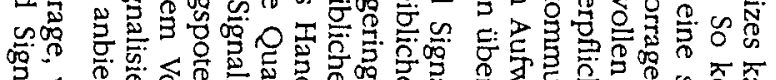

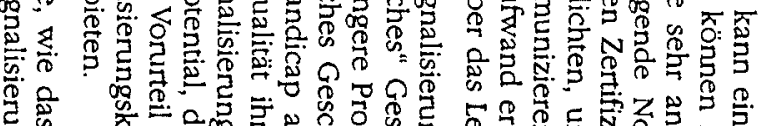

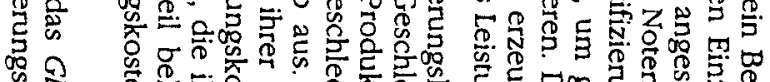

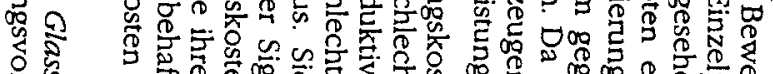

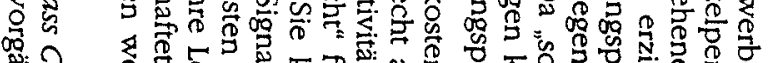

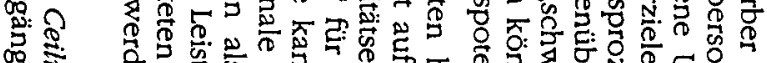

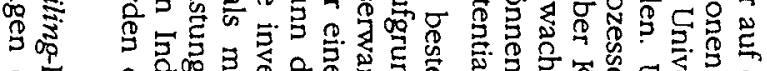

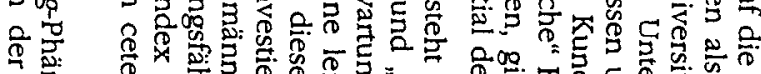

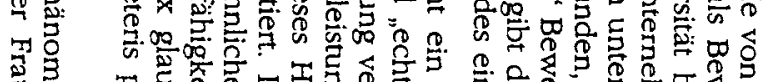

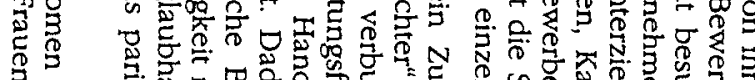

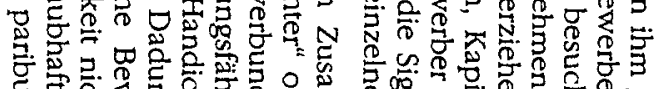

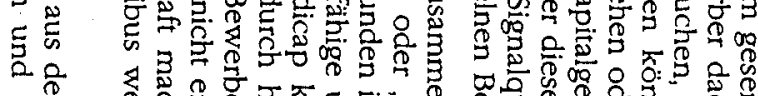

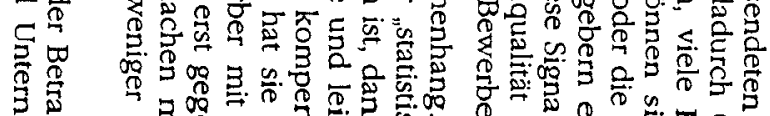
象学

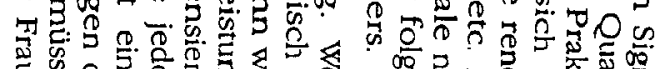

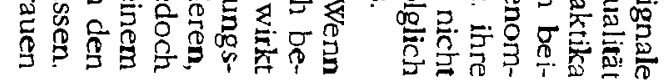

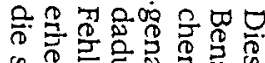

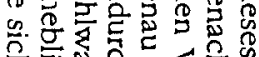

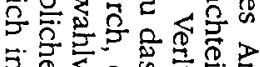

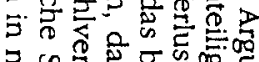

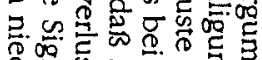

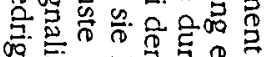

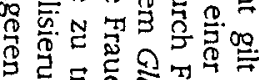

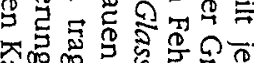
.

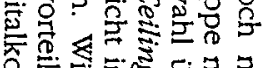

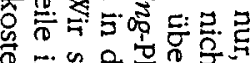

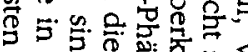

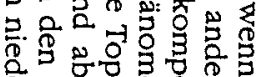

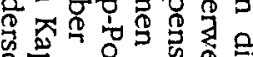

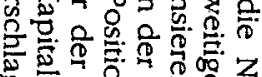
证可 을

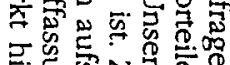

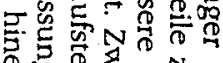
S.00

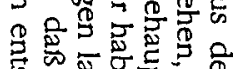

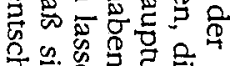

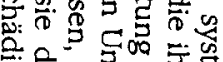

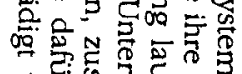

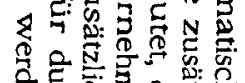

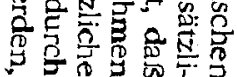




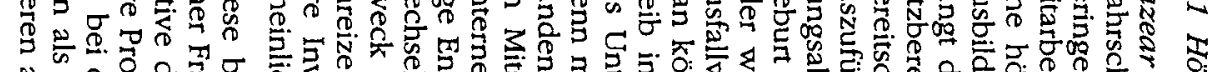

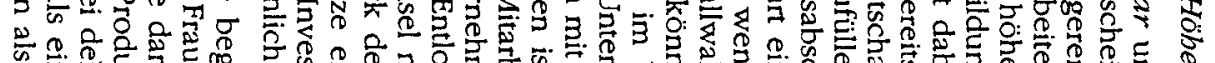

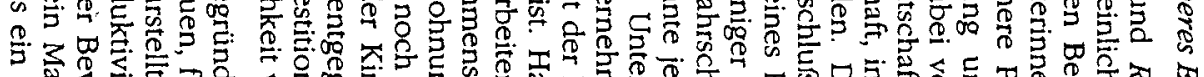

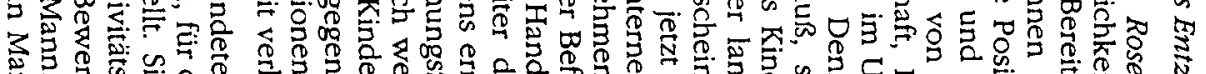

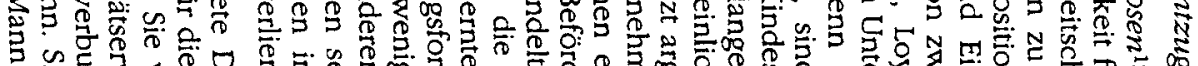

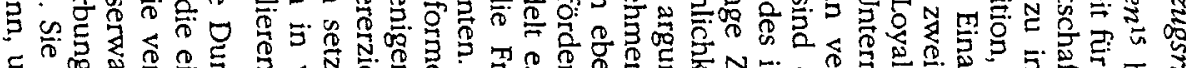

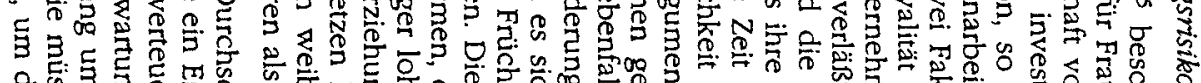

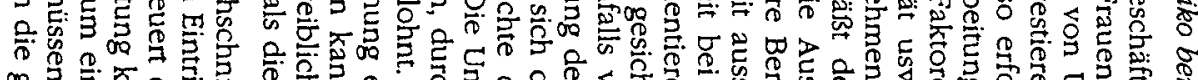
on

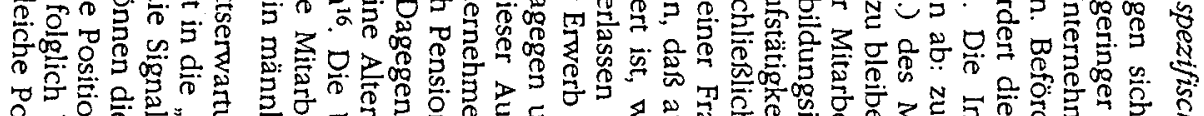

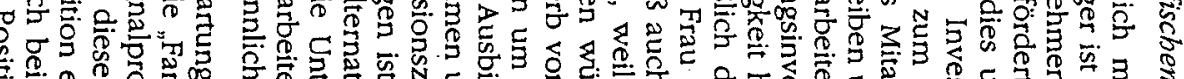

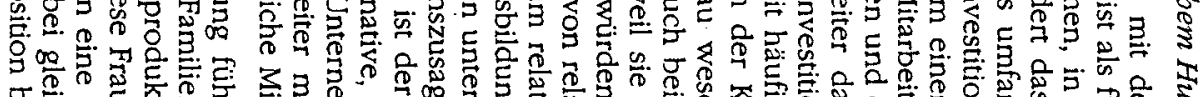

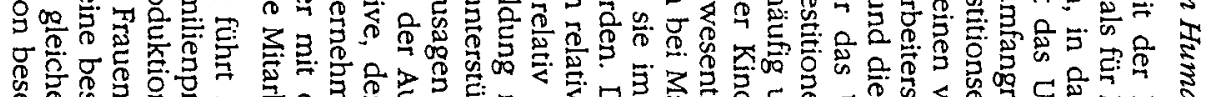

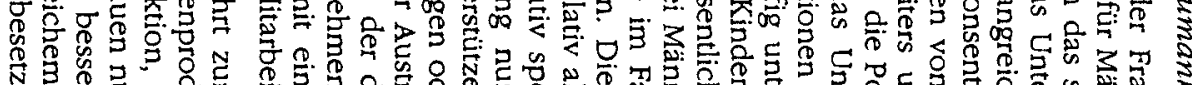

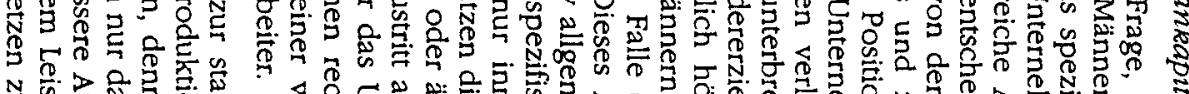

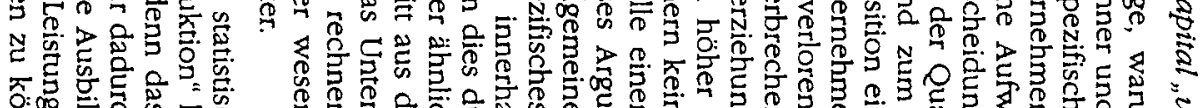

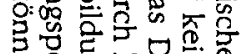

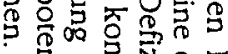

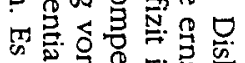

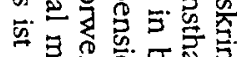

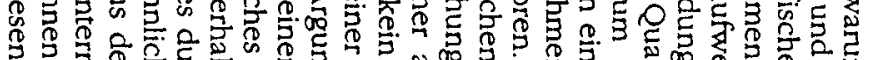
马)

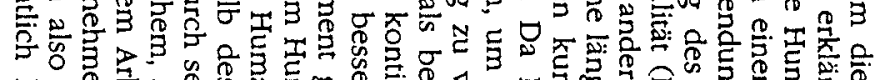

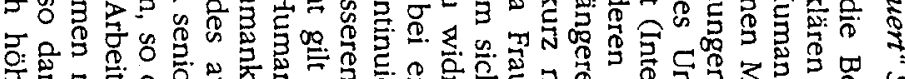

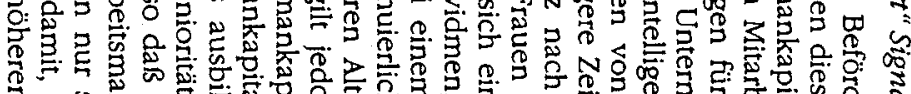

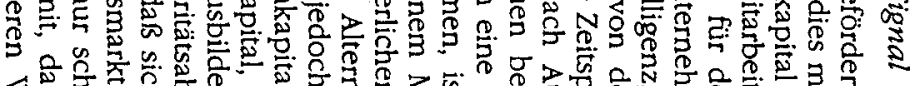

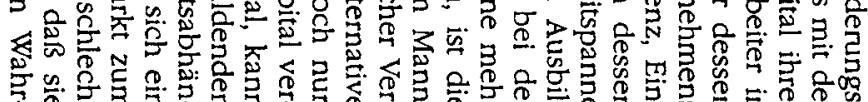

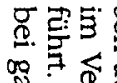

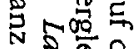

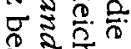

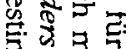

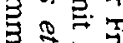

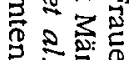

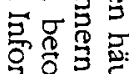

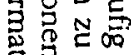

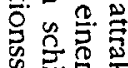

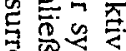

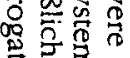

T.

莫高

音:

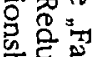

更

家 9

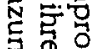

o

还 중

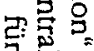

공중

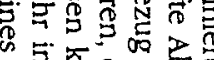

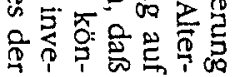

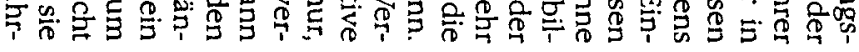

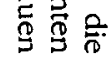

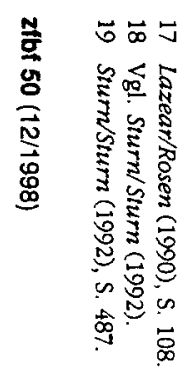

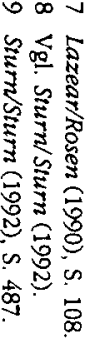

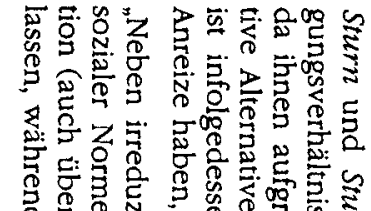

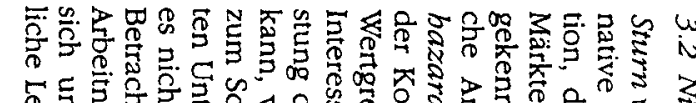

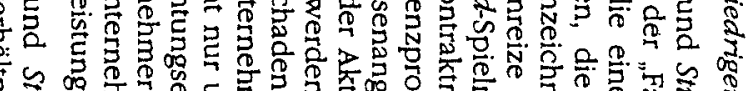

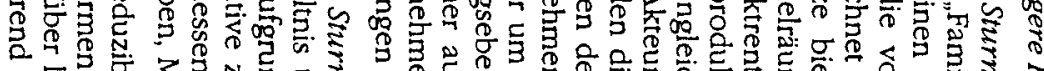

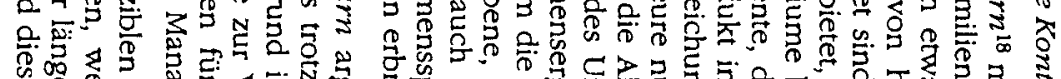

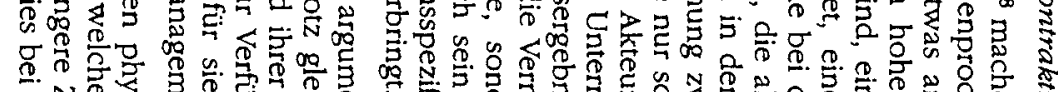

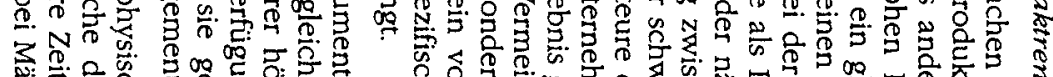

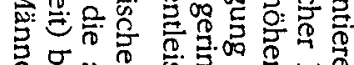

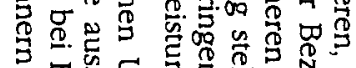

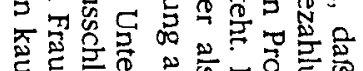

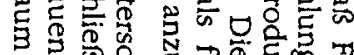

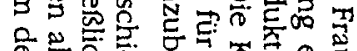

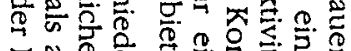

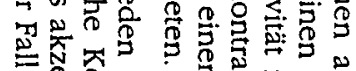
可?

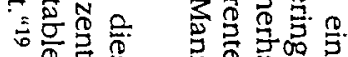
क्ष.

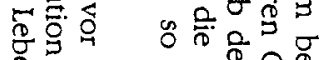

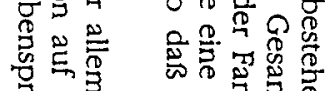

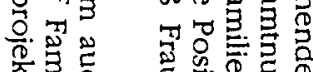

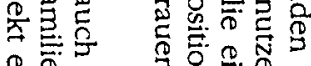

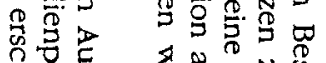

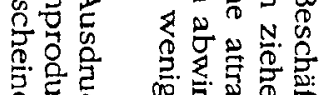

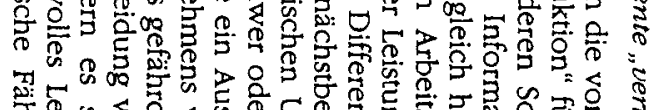

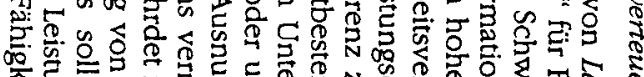

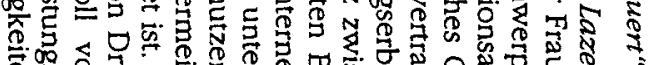

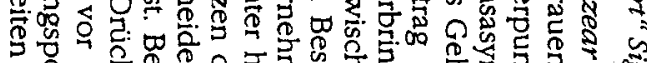

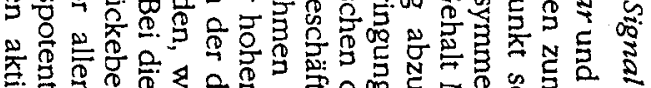

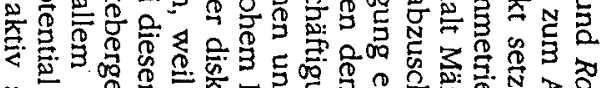

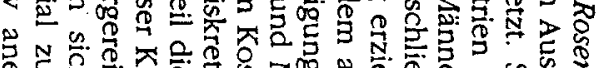

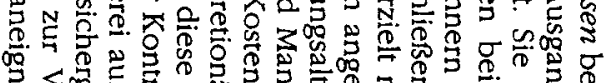
ప

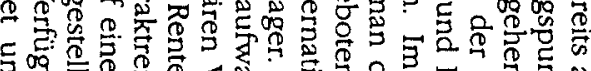

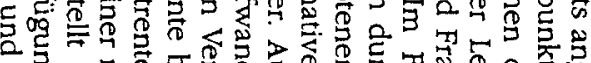
西

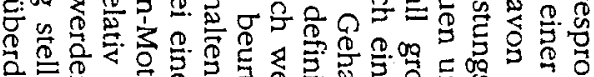

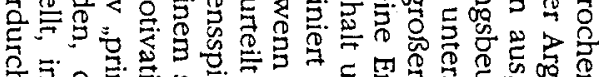
产

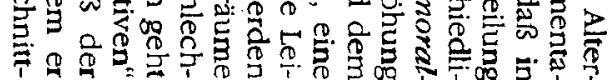

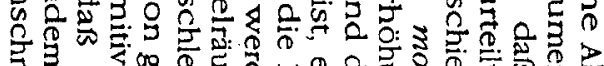

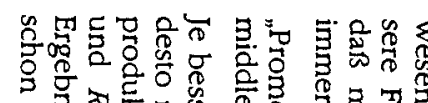

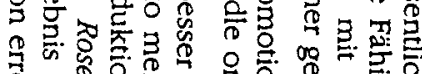
일

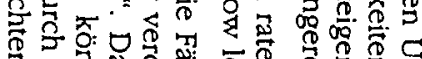

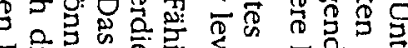

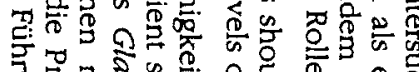

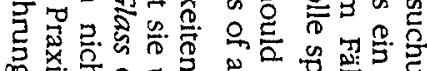
का

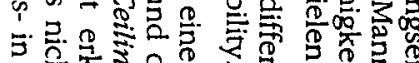

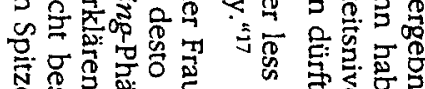

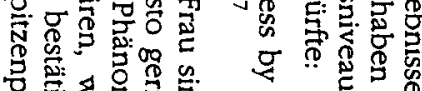

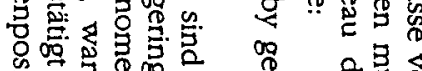

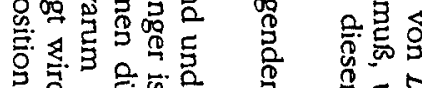

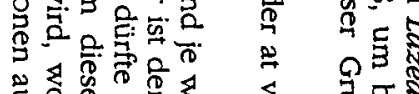

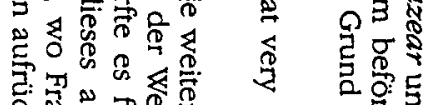

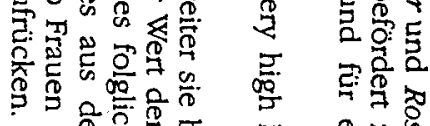

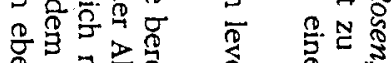

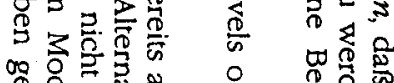

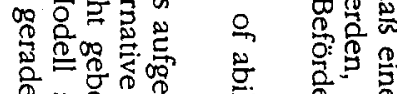

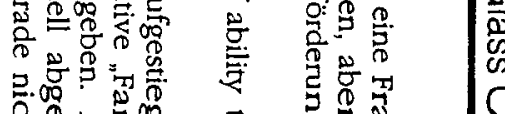

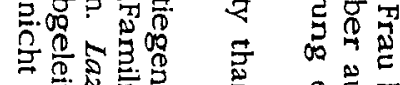

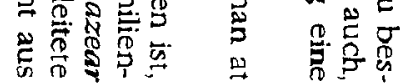




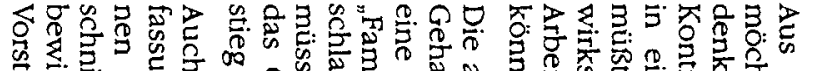

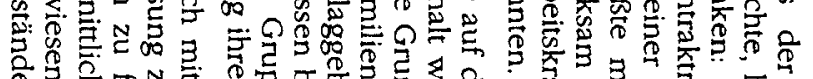

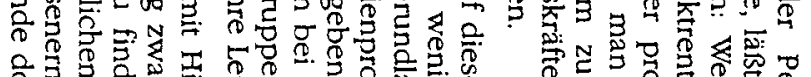

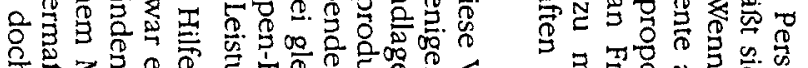

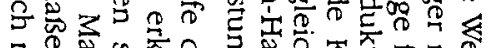

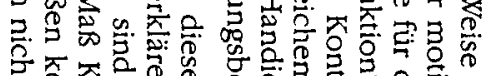

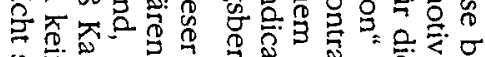

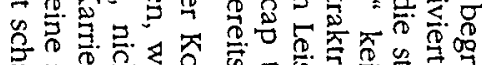

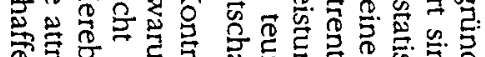

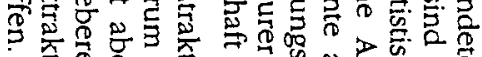

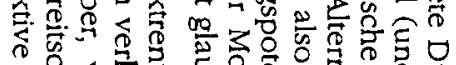

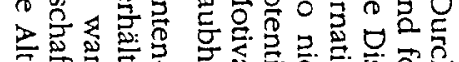

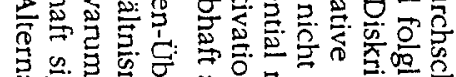

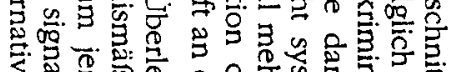

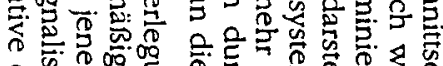

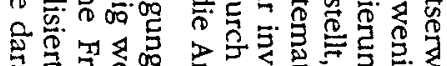
ज急

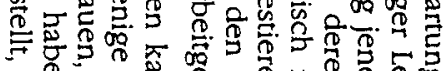

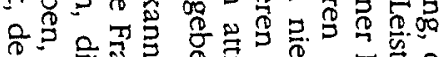
9 율 总

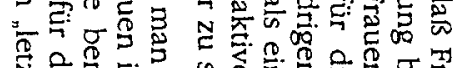

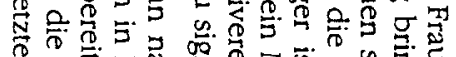

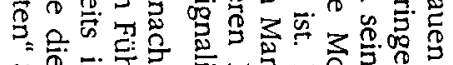

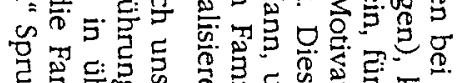

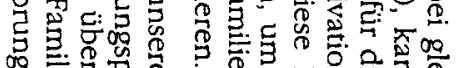
5.

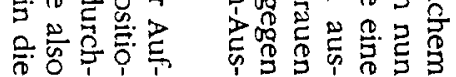

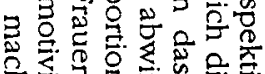
存

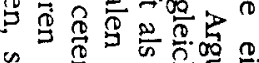

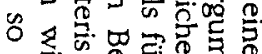
엉

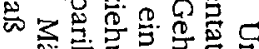

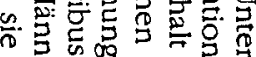

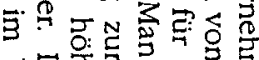

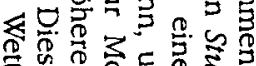

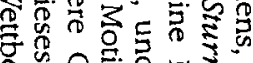

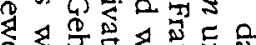
管

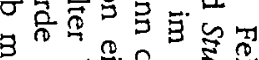

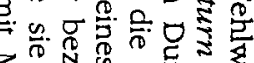

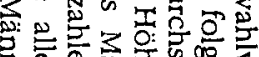

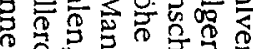
5

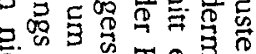

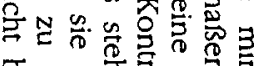
两 6 管

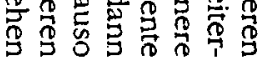




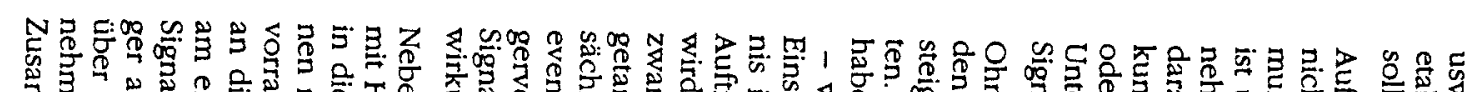

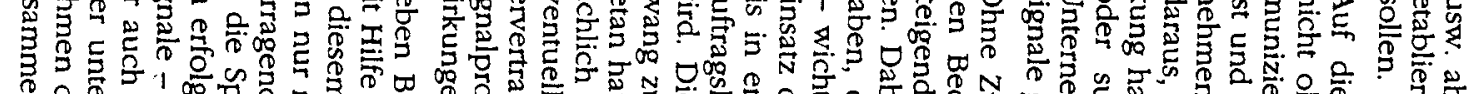

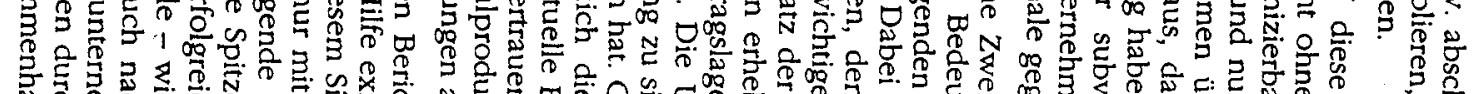

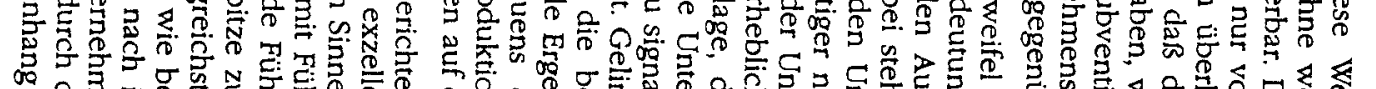

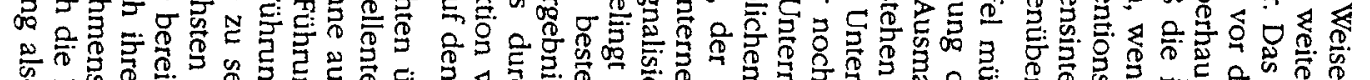

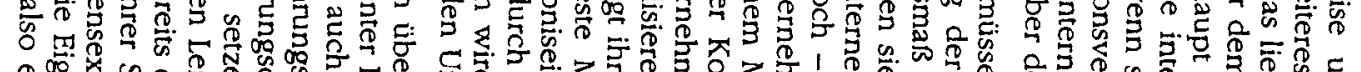
罂.

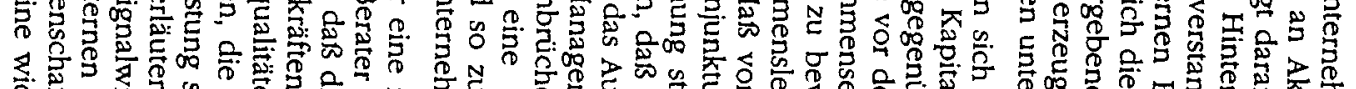

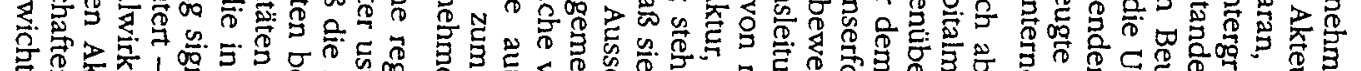

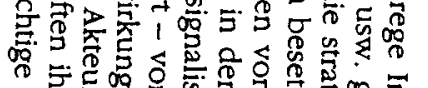

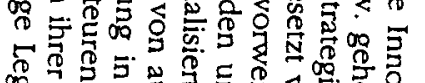

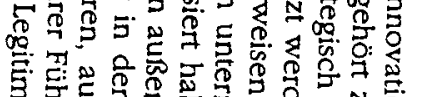

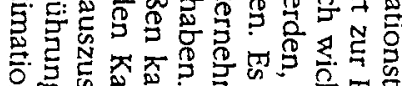

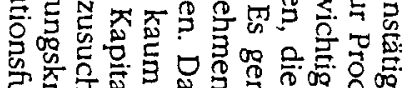

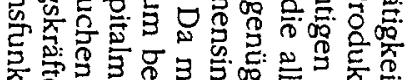
적

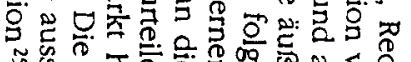

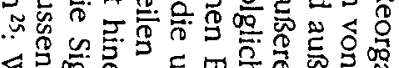

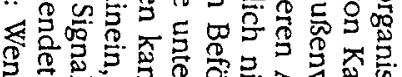

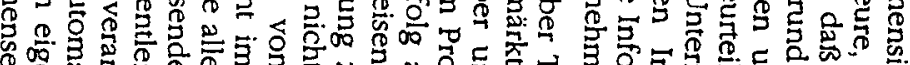

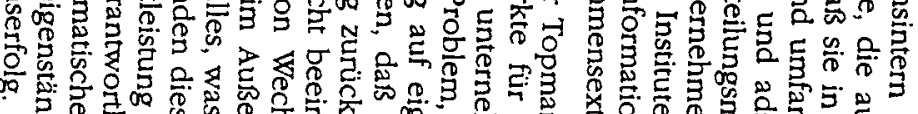

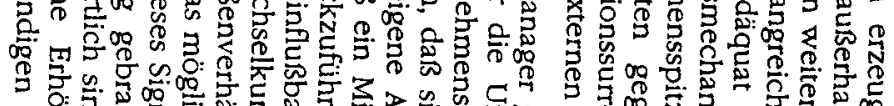

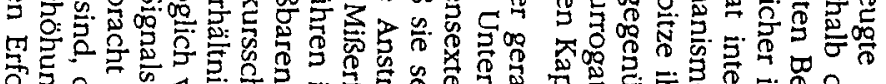

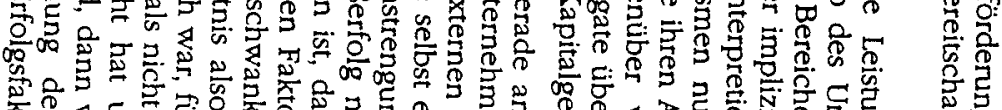

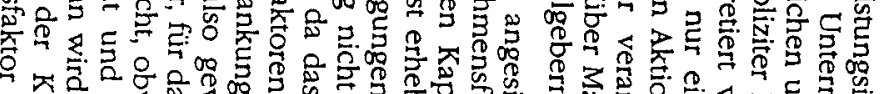

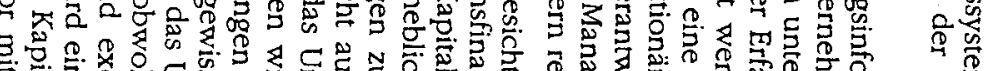

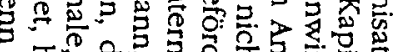

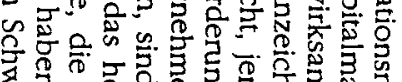

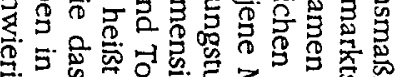

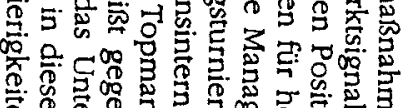

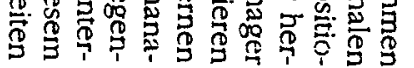

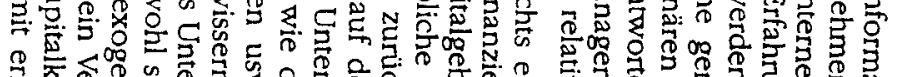

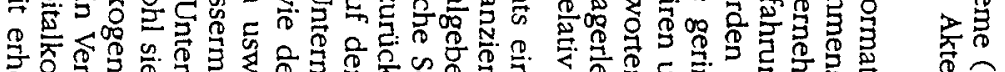

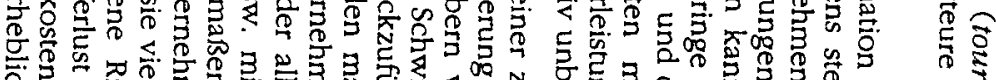

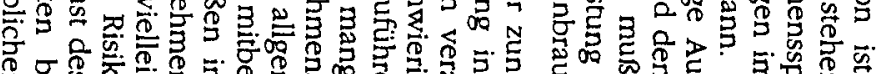

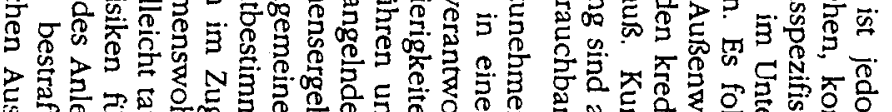

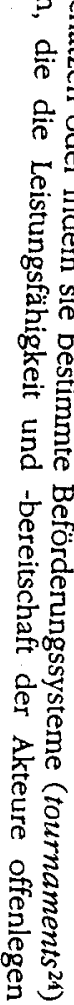

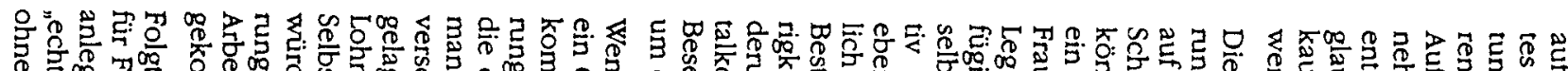

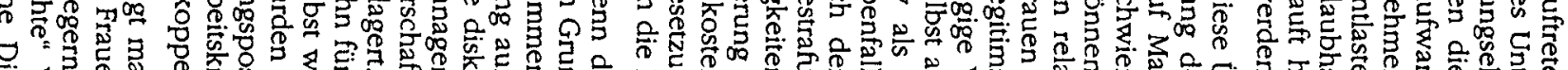

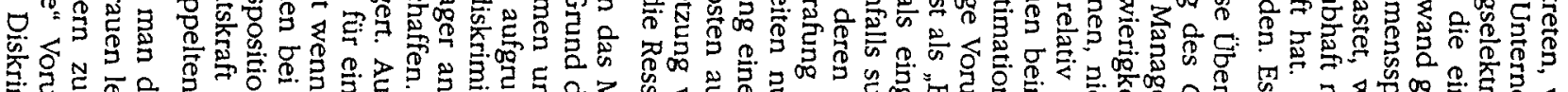

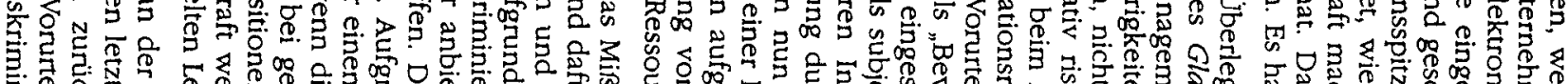

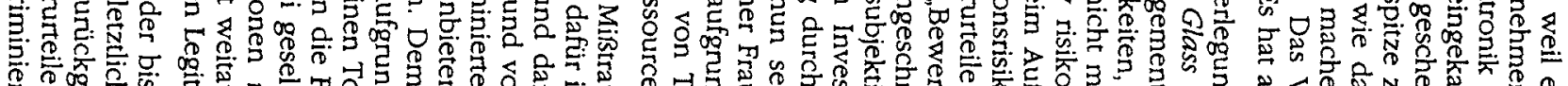

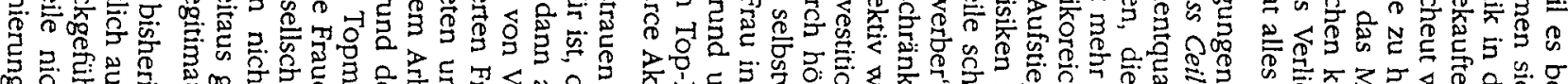

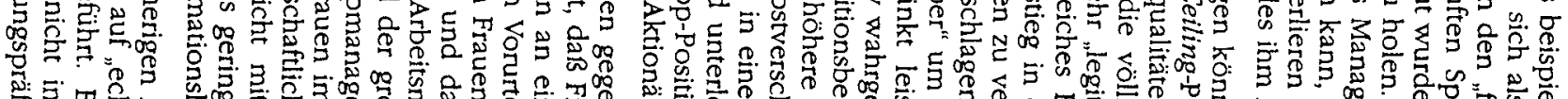

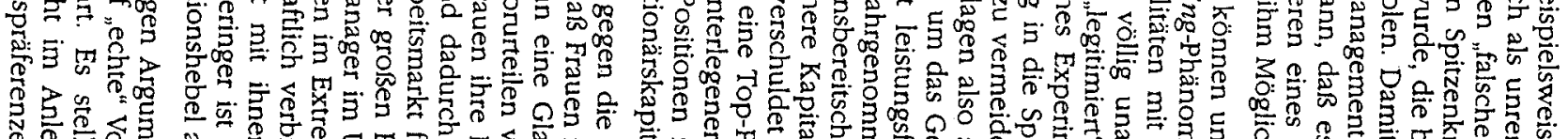

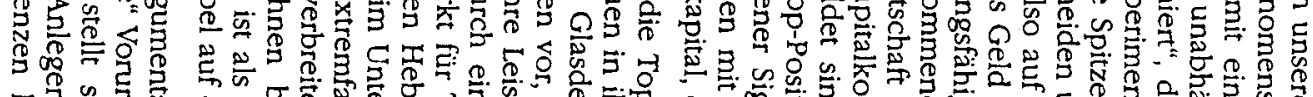

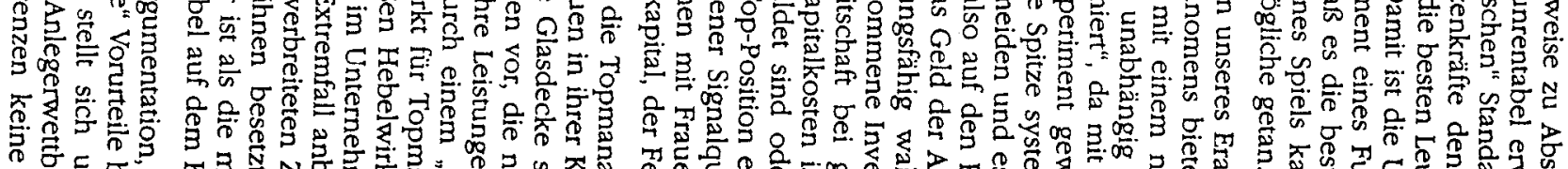

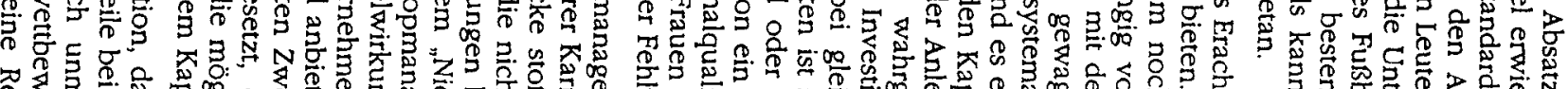

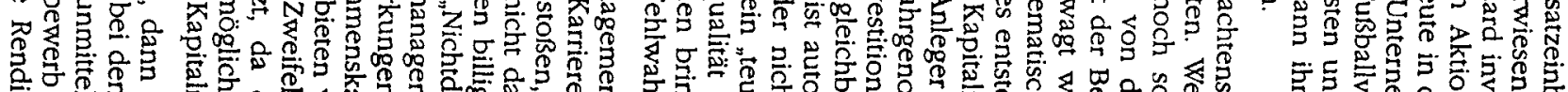

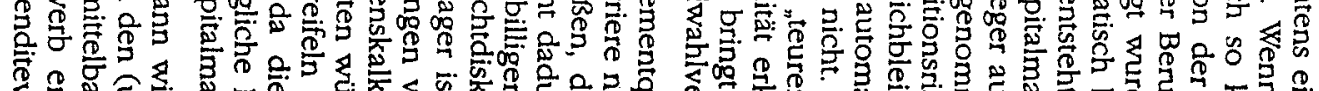

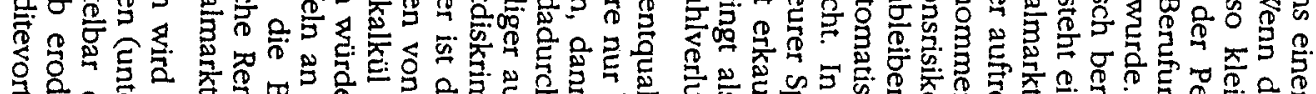

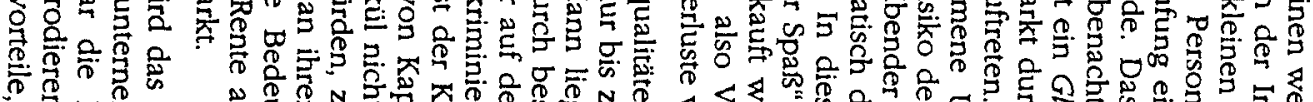

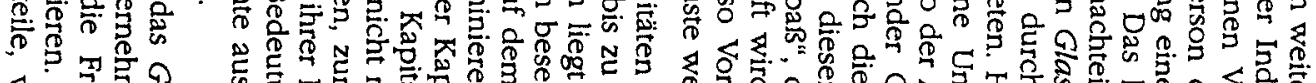

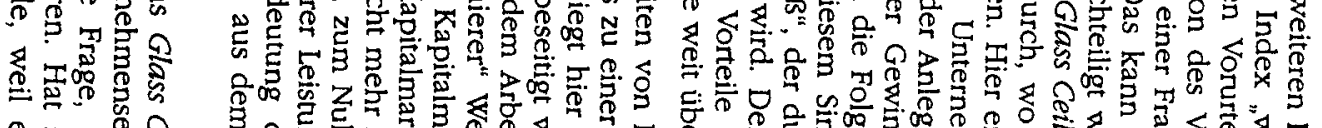

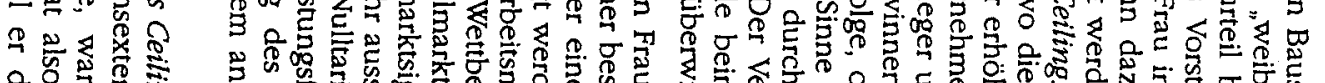

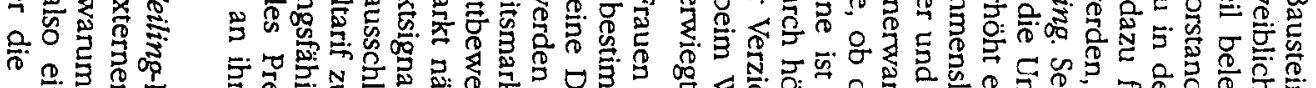

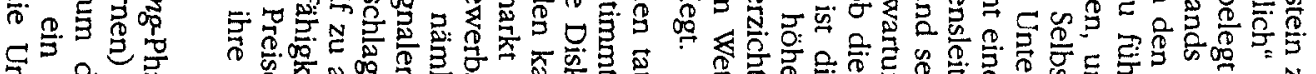

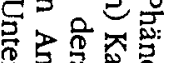

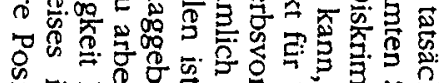

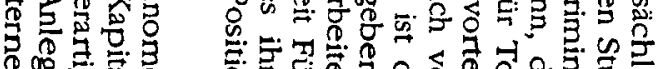

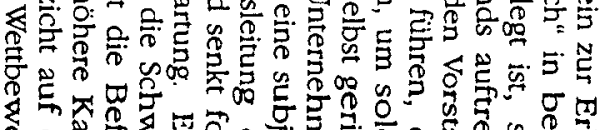

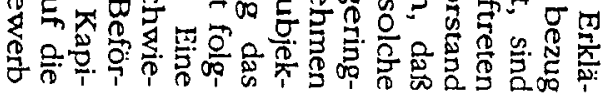

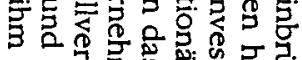

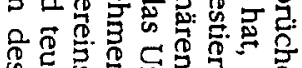

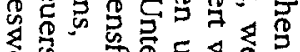

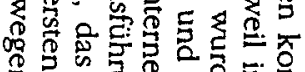

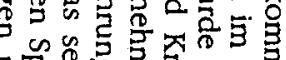

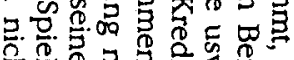

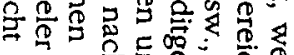

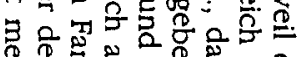

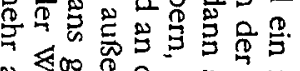

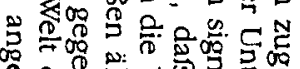

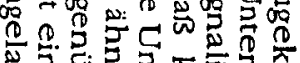

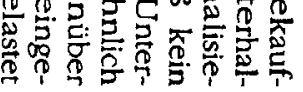




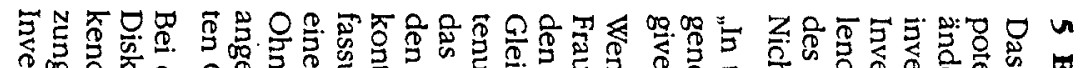

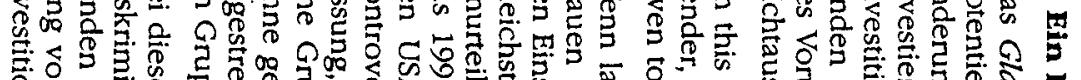

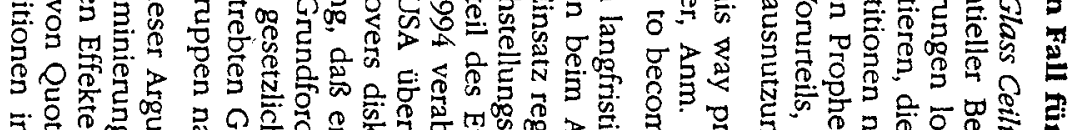
马

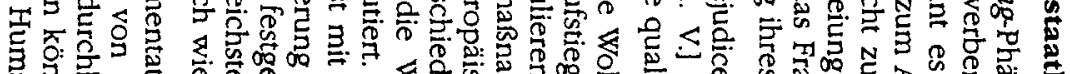

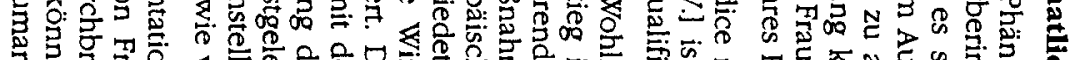

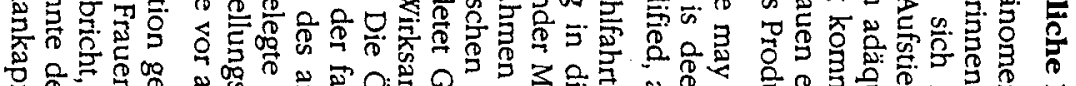

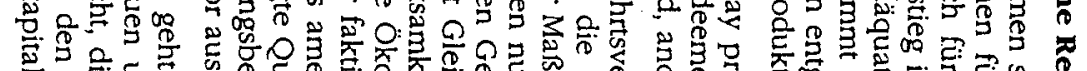

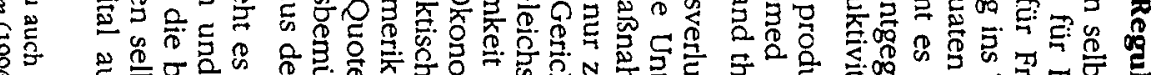

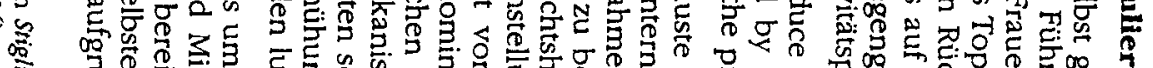

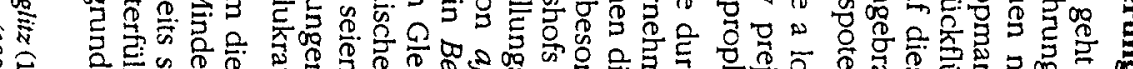

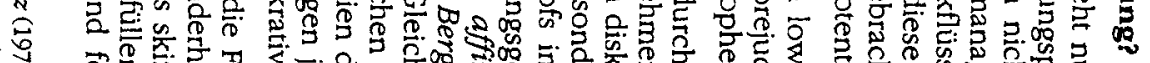

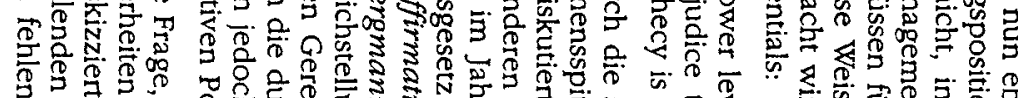

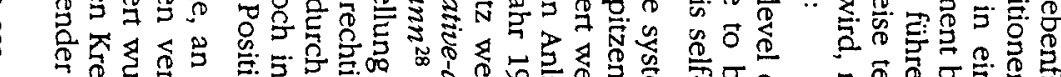

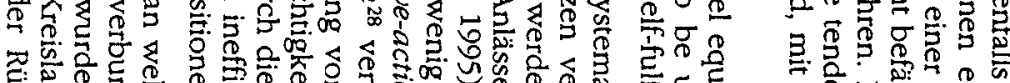

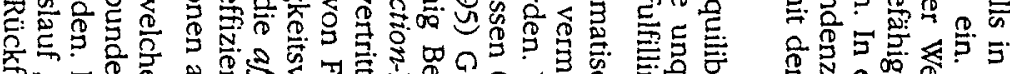

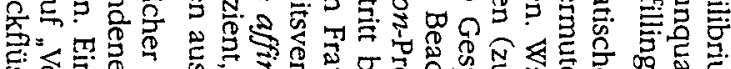

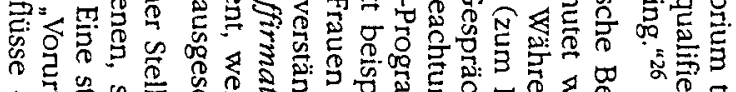

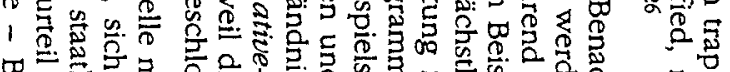

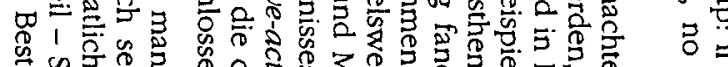
줄 on

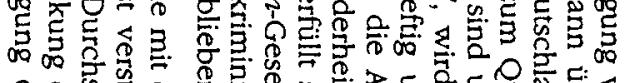

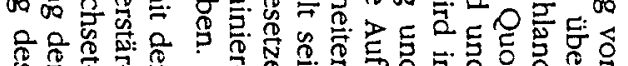

要送 S․

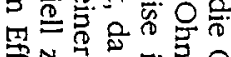
蛋

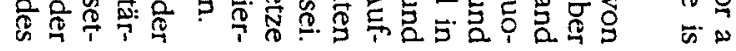

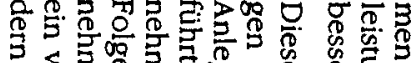

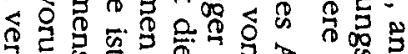

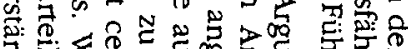

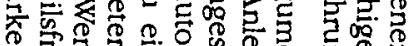

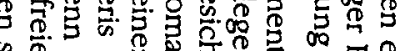
. 을.

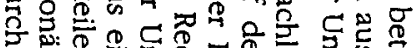
ㄴ. co z)

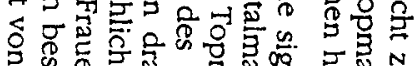

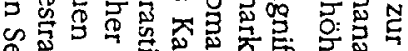

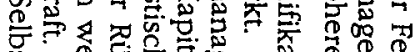

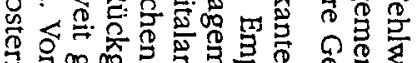

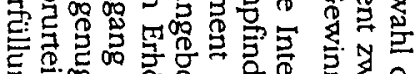
5 D.00

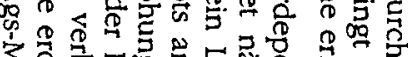

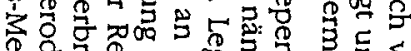

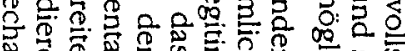

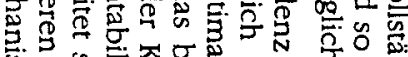

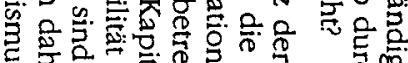
的零 ㄹ. $\Rightarrow$ 急

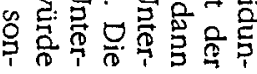

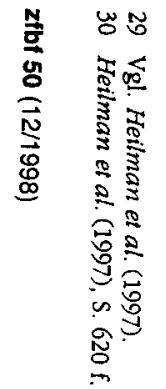

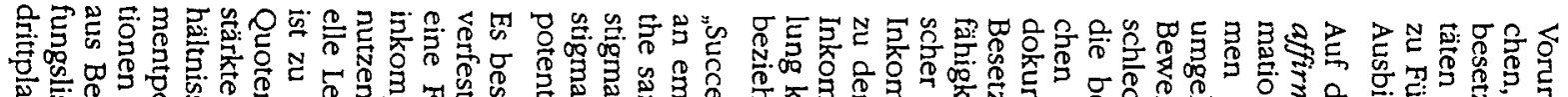

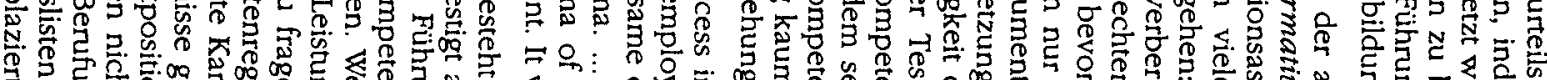

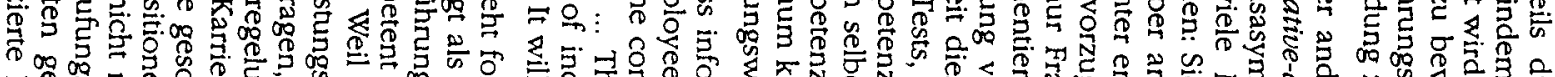

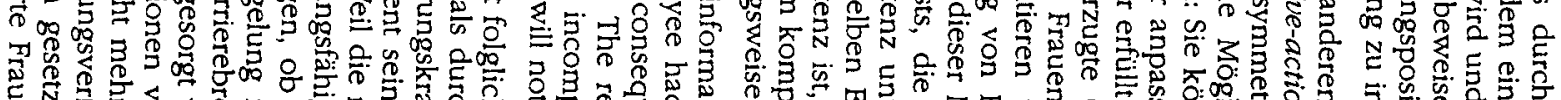

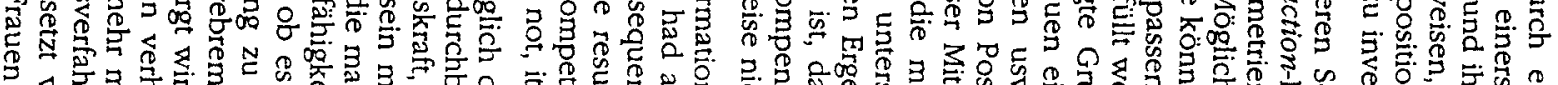

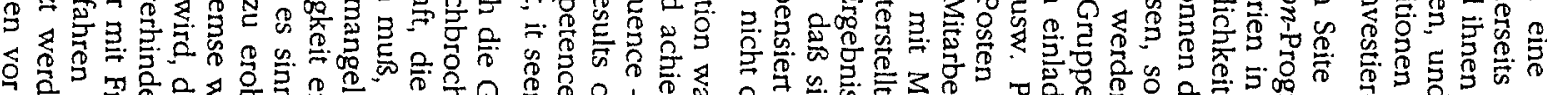

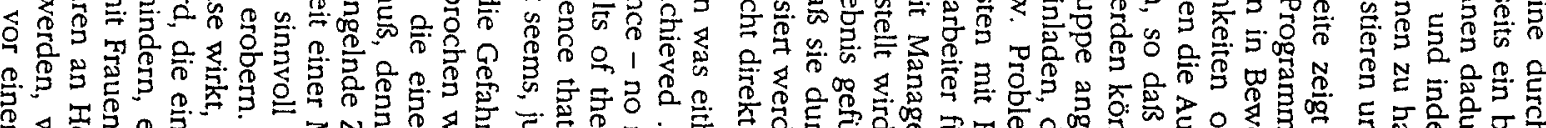

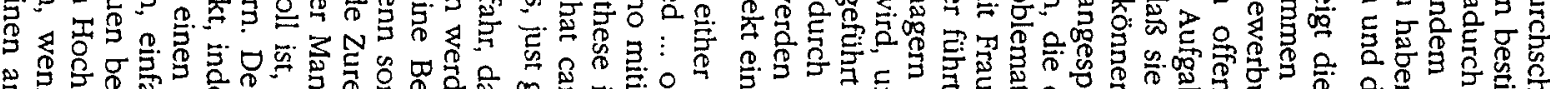

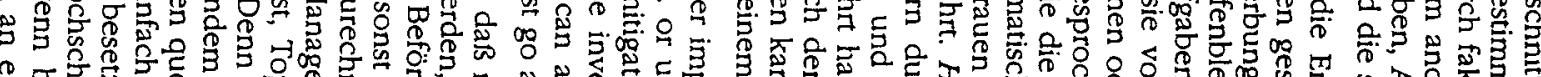

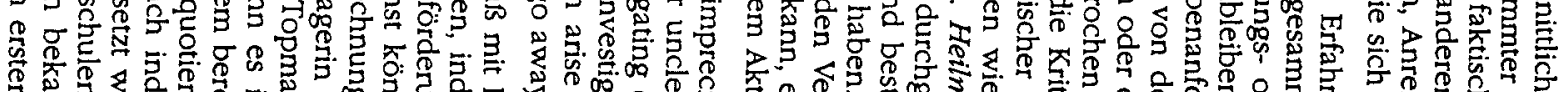

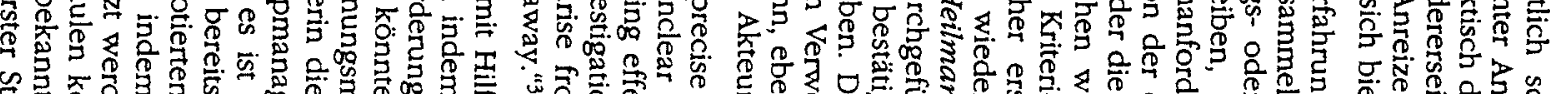

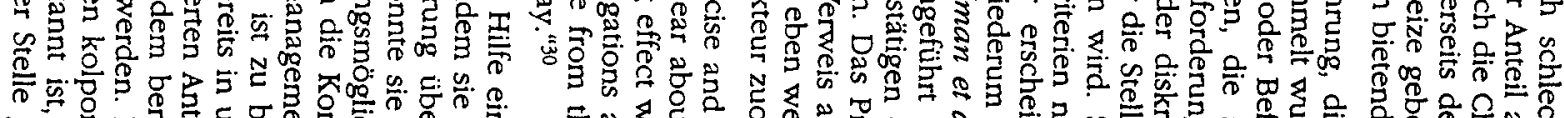

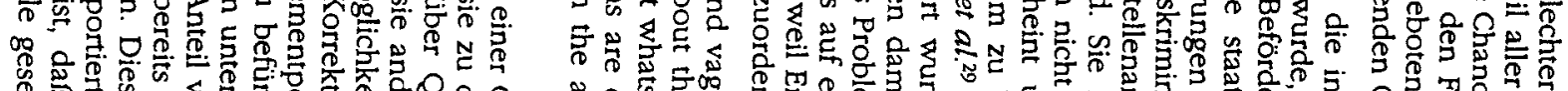

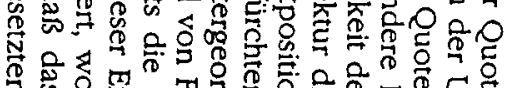

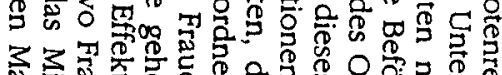

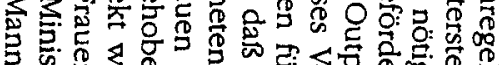
T)

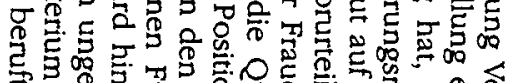

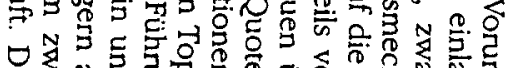

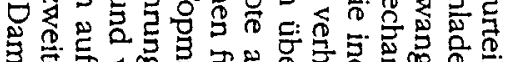

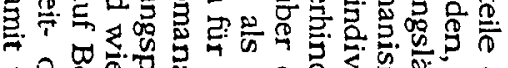

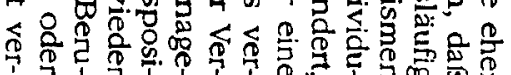

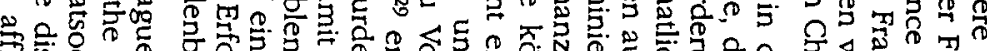
3.

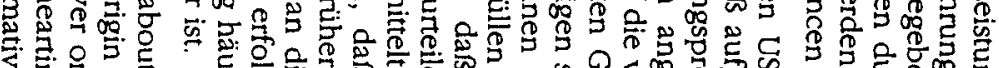

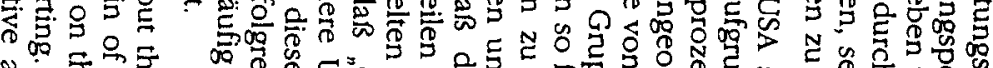

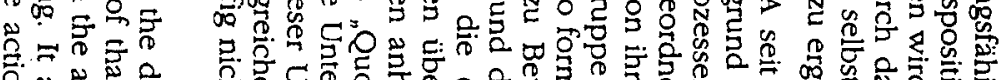

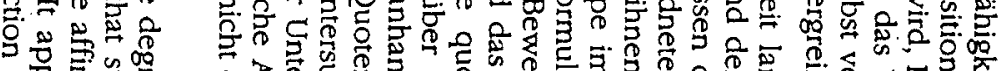

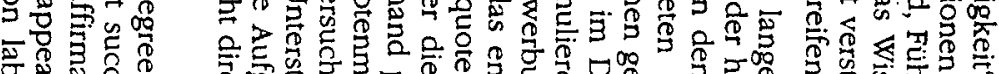

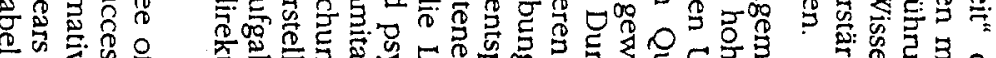

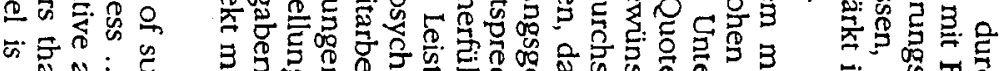

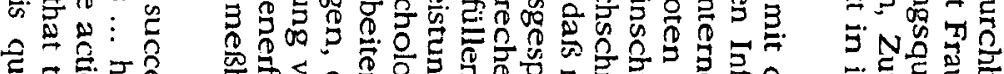

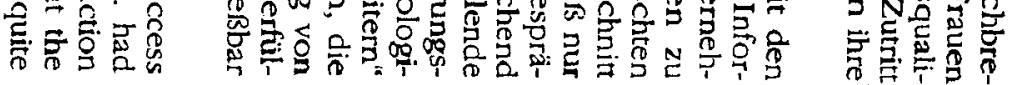




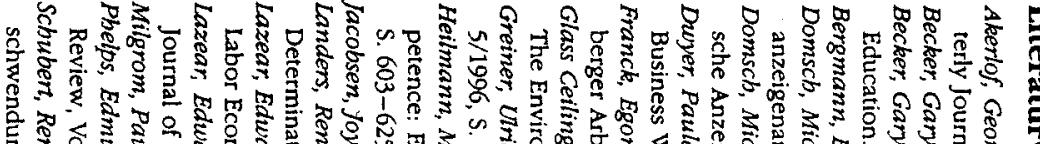

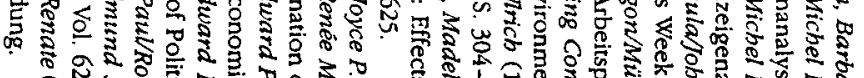

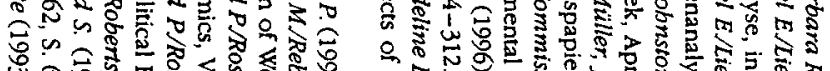

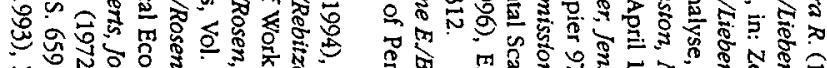

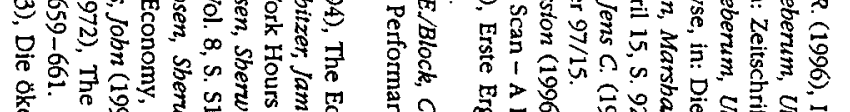

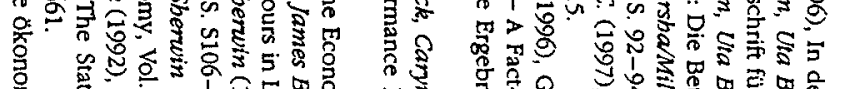

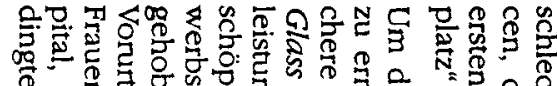

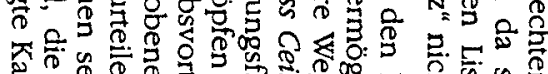

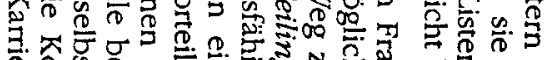

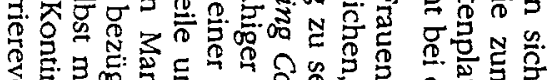

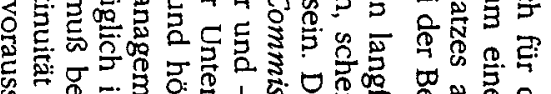

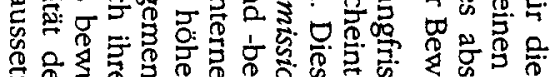

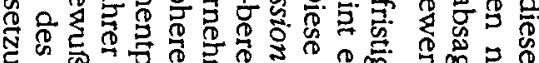

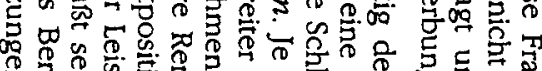

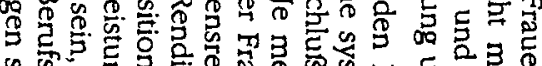

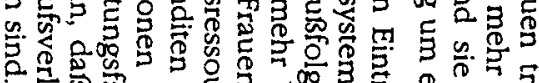

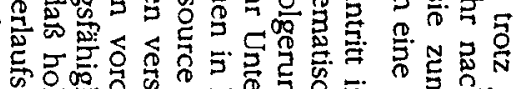

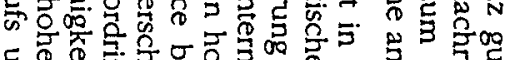

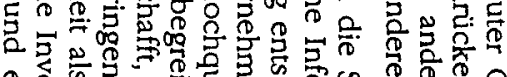
ه.

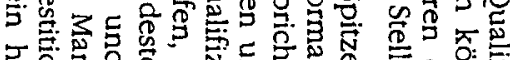

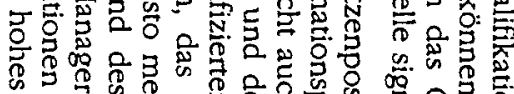
З5.

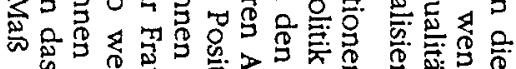

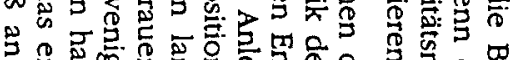

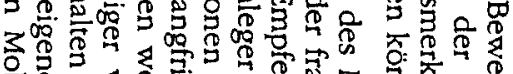

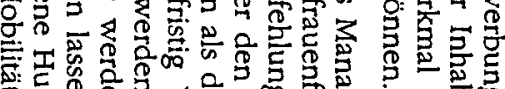

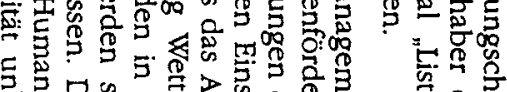

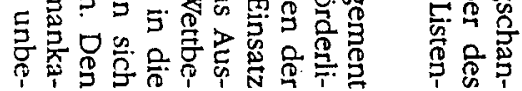

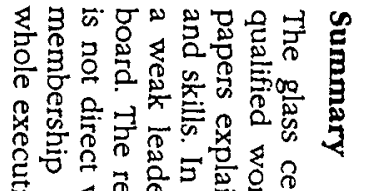

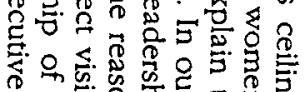

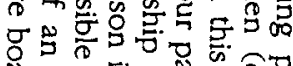

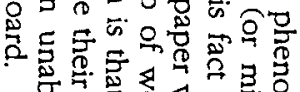

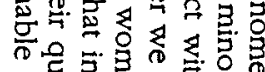

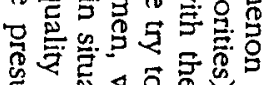

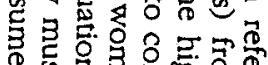

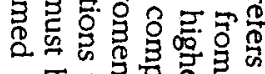

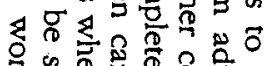

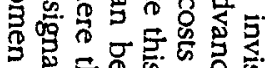

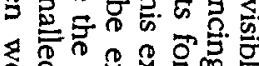

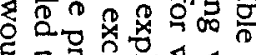

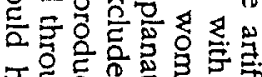

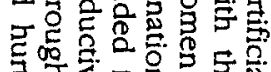

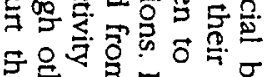

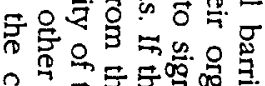

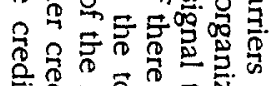

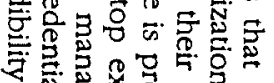

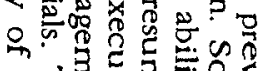

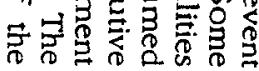

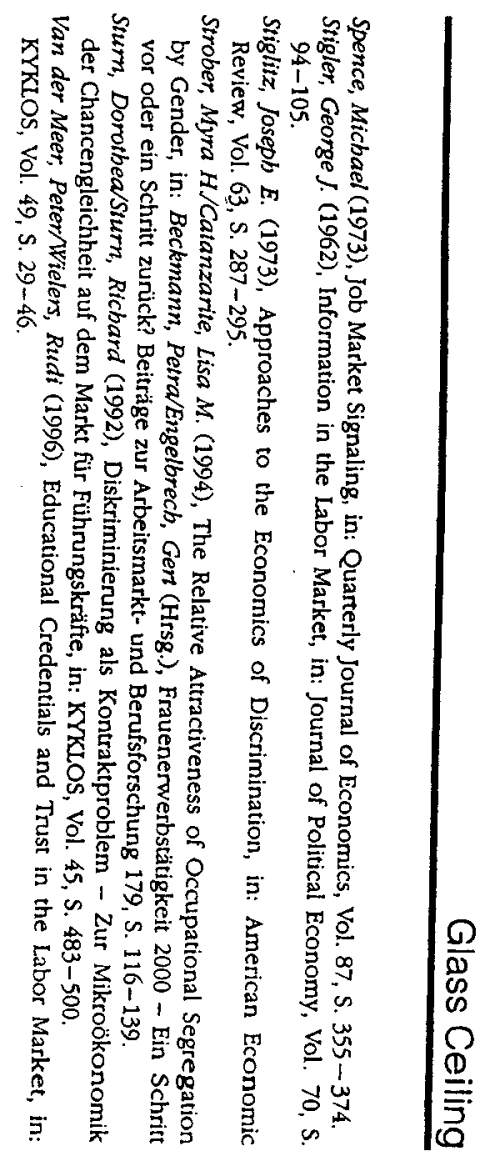

